\title{
Perceptions of Students, Faculty, and Staff Concerning Visitation Dogs on College Campuses
}

Brieanna Hughes

Follow this and additional works at: https://researchrepository.wvu.edu/etd

\section{Recommended Citation}

Hughes, Brieanna, "Perceptions of Students, Faculty, and Staff Concerning Visitation Dogs on College Campuses" (2018). Graduate Theses, Dissertations, and Problem Reports. 7190.

https://researchrepository.wvu.edu/etd/7190

This Thesis is protected by copyright and/or related rights. It has been brought to you by the The Research Repository @ WVU with permission from the rights-holder(s). You are free to use this Thesis in any way that is permitted by the copyright and related rights legislation that applies to your use. For other uses you must obtain permission from the rights-holder(s) directly, unless additional rights are indicated by a Creative Commons license in the record and/ or on the work itself. This Thesis has been accepted for inclusion in WVU Graduate Theses, Dissertations, and Problem Reports collection by an authorized administrator of The Research Repository @ WVU. For more information, please contact researchrepository@mail.wvu.edu. 

Perceptions of Students, Faculty, and Staff Concerning Visitation Dogs on College
Campuses

Brieanna Hughes

Thesis submitted

to the Davis College of Agriculture, Natural Resources and Design

at West Virginia University

in partial fulfillment of the requirements for the degree of

Masters of Science in

Agricultural and Extension Education

Jessica Blythe, Ph.D. Chair

Harry N. Boone Jr, Ph.D.

Lindsay Parenti, MA

School of Design and Community Development

Morgantown West Virginia

2018

Key words, visitation dogs, therapy dogs, perceptions, college campuses

Copyright 2018 Brieanna Hughes 


\begin{abstract}
Perceptions of Faculty Students and Staff Concerning Visitation Dogs on College Campuses
\end{abstract}

Brieanna G. Hughes

The main purpose of this descriptive study was to describe how students, faculty, and staff are perceiving the use of visitation and therapy dogs on college campuses. This study found that visitation and therapy dogs are being positively received by the campus community and West Virginia University. This study investigated respondent's general perceptions of dogs, perceived knowledge of the terms visitation dog, therapy dog, and service dog, perceptions of the use of visitation and therapy dogs on college campuses and perceptions of interactions of visitation and therapy dogs on college campuses. 


\section{DEDICATION}

I would like to dedicate this research to my grandparents, Irene and Paul Hurst and Marjorie and John Hughes. Your support, guidance, and faith helped one blessed and goofy girl become one tough and persistent woman. 


\section{ACKNOWLEDGMENTS}

I would like to acknowledge my parents Victoria L. Hughes and Andrew J. Hughes for your love and encouragement. I would not be the person I am today without the life you worked hard to provide for me.

I would like to acknowledge my academic advisor Dr. Jessica Blythe, and my research committee members Dr. Harry Boone and Lindsay Parenti for the endless edits, guidance, and especially for your patience.

A special thanks to Dawn Mackenzie for the endless life, academic, and health advice. You put up with much more than one person should be required to deal with in a friendship. Also a thank you to my friends near and far for countless phone conversations, support, and good laughs.

Last, but not least, I would like to acknowledge two very important mentors that shaped, prepared, and believed in me so that I could be successful in my future endeavors: Dr. Stephen Mackenzie and Tadeusz Sulkowski. I will always cherish the education provided and the life lessons learned from both of you. Do not doubt that without the confidence you instilled in me over my undergraduate career, I would not be where I am today. 


\section{TABLE OF CONTENTS}

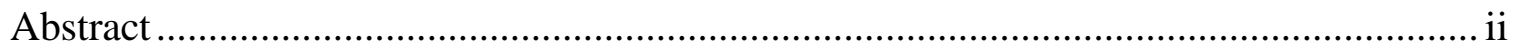

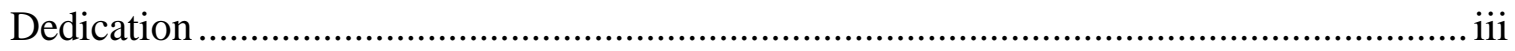

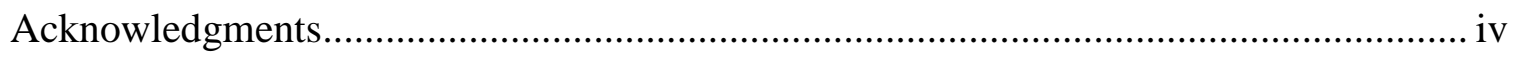

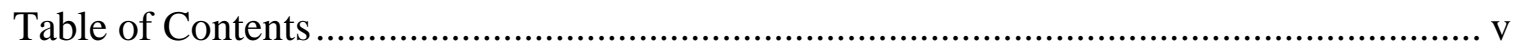

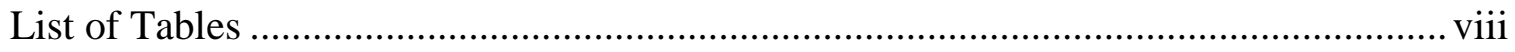

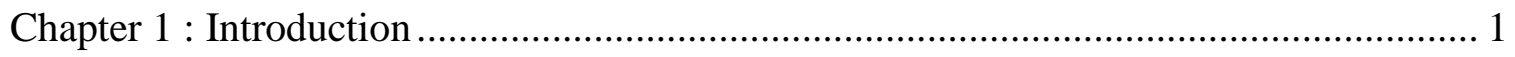

Statement of the Problem......................................................................... 3

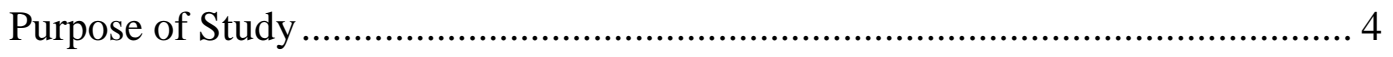

Objectives of the Study .............................................................................. 4

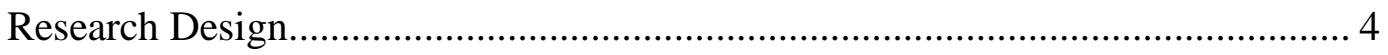

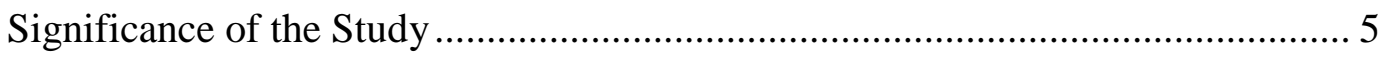

Limitations and Assumptions of the Study .................................................. 5

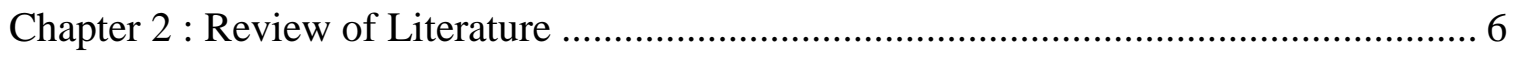

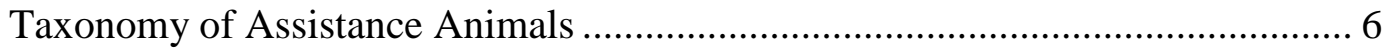

Health and Social Benefits of Visitation and Therapy Dogs .............................. 7

Student Stress on College Campus .......................................................... 8

Studies Including AAI on College Campuses .............................................. 8

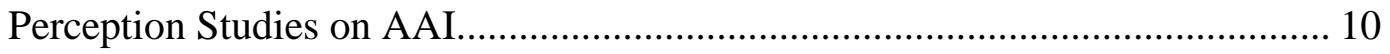

Chapter 3 : Methodology ................................................................................... 12 


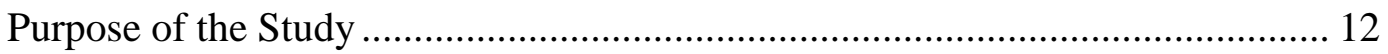

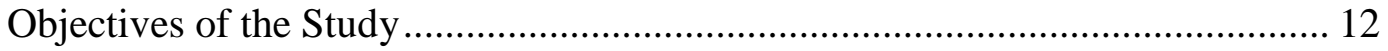

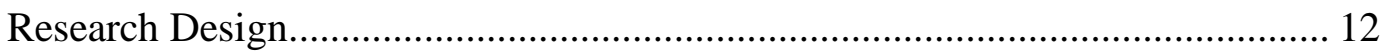

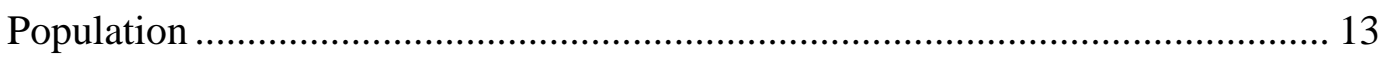

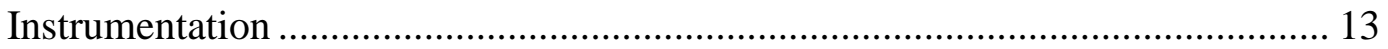

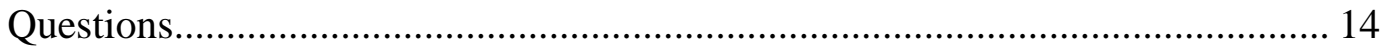

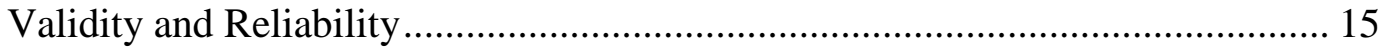

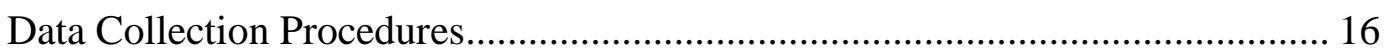

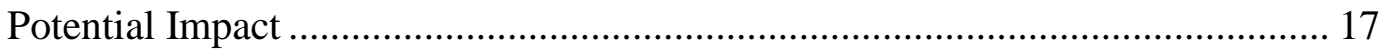

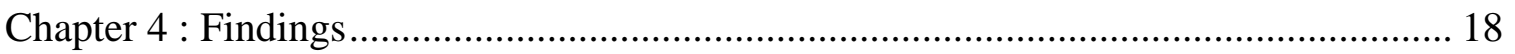

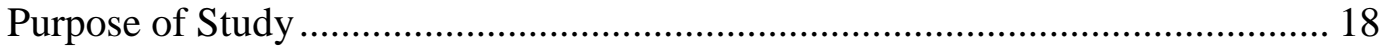

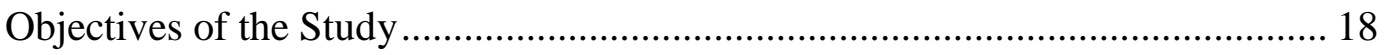

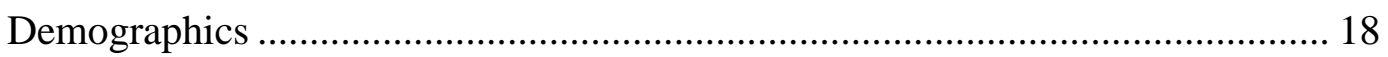

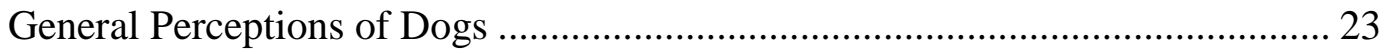

Student, Faculty, and Staff Respondent Comparisons...................................... 37

Comparison of International Students, International Faculty, and International Staff Members to Non- International Students, Faculty, and Staff...................... 43

Chapter 5 : Summary, Conclusions, \& Recommendations............................................ 48

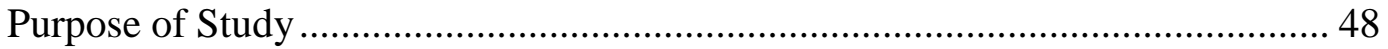

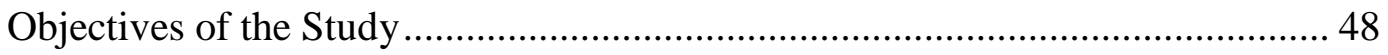


Summary, Conclusions and Discussion.............................................................. 48

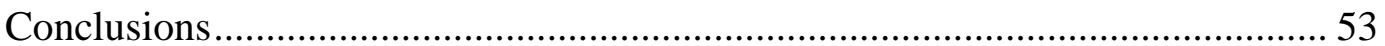

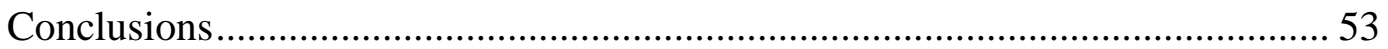

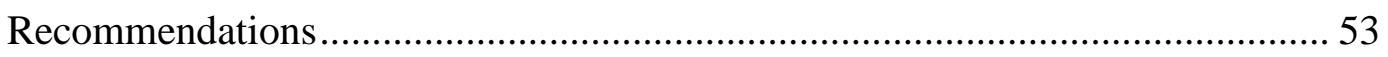

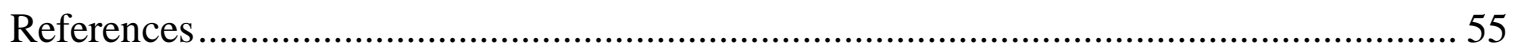

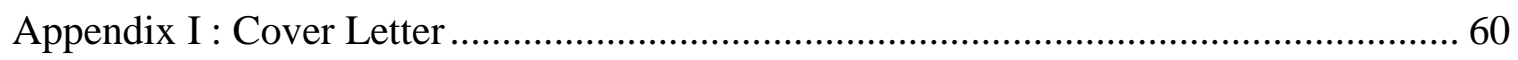

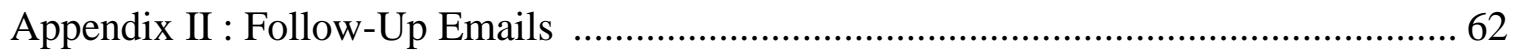

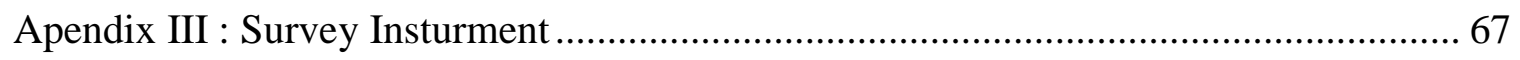




\section{LIST OF TABLES}

1 Reliability of Major Parts of Instrument .................................................................... 16

2 Student, Faculty, or Staff Member Demographics …………………........................ 19

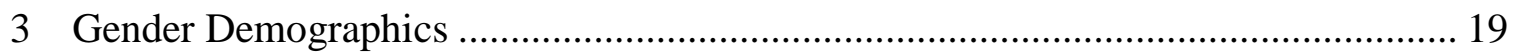

5 International Student, International Faculty, International Staff Demographics........ 20

6 Ethnicity Demographics.................................................................................... 20

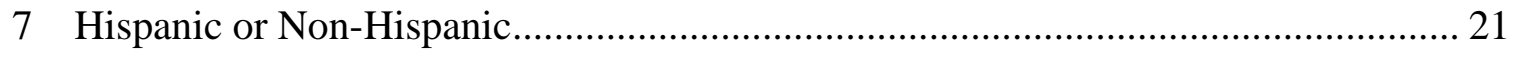

8 Suburban, Rural or Urban .............................................................................. 21

9 Respondent Age Range......................................................................................... 22

10 Respondents’ History with Dogs in General ......................................................... 22

11 General Perceptions of Dogs ..................................................................... 26 \& 27

12 Perceived Knowledge of Terms........................................................................ 28

13 Perceptions of Having Visitation or Therapy Dogs on Campus................................ 30

14 Frequency of Interactions of Students, Faculty, and Staff with Visitation and

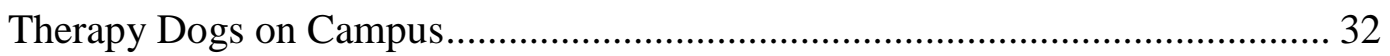

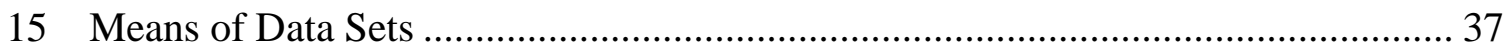

16 Student, Faculty, and Staff Comparisons.............................................................. 38

17 Analysis of Variance: General Perceptions of Dogs, Perceived Knowledge of Terms, General Perception of Dogs on Campus and Perception of Interactions with Dogs on Campus by Students, Faculty, and Staff Respondents 
18 Comparison of Mean Scores of International Students, International Faculty, and International Staff Compared to Non-International Students, International Faculty, and International Staff Members for Each Construct 47 


\section{CHAPTER 1}

\section{Introduction}

Animal Assisted Intervention (AAI) is a term which encompasses a variety of activities and therapies intended to use animals to benefit human wellbeing (Bibbo, 2013; Fine \& Beck, 2010). More specifically, within AAI there are Animal Assisted Therapies (AAT) and Animal Assisted Activities (AAA). AAI is becoming a popular way to provide stress relief for students on college campuses (Muckle \& Lasikiewicz, 2017). Nine hundred and twenty-five canine visitation programs are being implemented at universities in the United States (Crossman \& Kazdin, 2015). For example, at Harvard Medical School's Countway Library, dogs were incorporated as a therapeutic tool for students to interact with during times of stress (Blogger, 2011).

Often, college students enter new social networks, become separated from their families, and are forced to adjust to new living circumstances (Jalongo \& McDevitt, 2015). During the transition into college, students become vulnerable to developing or increasing symptoms of depression (Lee, Dickson, Conley, Holmbeck, 2014).

Subsequently, higher education institutions have witnessed a rise in mental health issues in students due to stress (Muckle \& Lasikiewicz, 2017). Students suffering from mental health issues report less campus engagement, struggle with peer and faculty relations, and have lower grades and lower graduation rates (Byrd \& McKinney, 2012). Sources of stress in college students include: financial, academic, family, and social circumstances (Brougham, Zail \& Miller, 2009). To deal with these stressors, college students need assistance with both emotional balance and academic success (Jalongo \& McDevitt, 2015). 
Studies have supported the potential of AAI for helping students deal with stress, transitioning, and anxiety, as well as increasing attendance to voluntary events. (Friesen \& Beck, 2009; Daltry \& Mehr, 2015). In a study at Virginia Commonwealth University, students reported a significant decrease in perceived anxiety and loneliness after participating in AAA. Additionally, a study done at two universities in Singapore reported a reduction in student blood pressure and perceived anxiety after participating in AAA. In the same study, students who had low self-esteem and anxiety levels benefited the most from AAA, suggesting that visitation and therapy animals on college campuses can improve student wellbeing (Muckle \& Lasikiewicz, 2017).

Since dogs are the most common animal used for visitation and therapeutic purposes (Wells, 2009), it is important to recognize the cultural differences of students, faculty, and staff on college campuses and understand how cultural differences may affect perceptions of the use of visitation and therapy dogs (Jalango, Astorini \& Bomboy, 2004). While the benefits of using dogs are well-noted anecdotally, the use of animals near humans can cause discomfort among members of some cultures. Many higher education institutions desire to cultivate an environment that will flourish in a globalized and diverse society (Bowman, 2014). If students are fearful of animals used in AAI, the benefits will fall short (Jalongo \& Astroino, 2004). Unless negative perceptions of AAI are considered, AAI may not be accepted in the future (Jalondo \& Astroino, 2004). Diversity is a desired outcome of higher education, and understanding perceptions of AAI in diverse settings will be pertinent in improving and maintaining the use of AAI.

Studies specifically exploring the use of visitation and therapy dogs on college campuses have found inconsistencies in regulations and standards (Haggerty \& Mueller, 
2017). For example, some programs utilize dogs trained by a national or local organization, while others do not. Additionally, the location of visitation and therapy dogs on campuses can vary greatly; dogs can be found in administration offices, health care centers, libraries, or at specified locations at specific times (Haggerty \& Mueller, 2017). Students are the population intended to receive the benefit of AAI; however, faculty and staff are also interacting with visitation and therapy dogs on campus. For AAI to be successful, location, environment, and staff members must be considered (Moody, King, \& O’Rourke, 2002). This study seeks to better understand the entire college community's perceptions of the use of visitation and therapy dogs on campus to support best practices of AAI in higher education.

\section{Statement of the Problem}

Although there is great deal of research supporting the therapeutic and social benefits of visitation and therapy dogs, much of this research is being done in a controlled setting with small populations and a homogenous demographic. However, little of this research has been conducted using the entire college community, despite the recent uptick of therapy and visitation dogs on many college campuses. The use of visitation and therapy dogs may affect students, faculty, and staff; thus, it is important to understand if the intended implications of these animals are being perceived positively by the community utilizing them. Colleges promote diverse and inclusive environments, and as more colleges seek to improve stress levels using AAI, it is imperative to take into account the perceptions of those interacting with visitation and therapy dogs. 


\section{Purpose of Study}

This study was conducted with three core purposes. The first purpose was to explore how students, faculty, and staff perceive dogs in general. The second purpose sought to describe how students, faculty, and staff perceive visitation and therapy dogs on West Virginia University Campuses. The third purpose sought to determine if the diverse population on college campuses affects the perceptions of visitation and therapy dogs on West Virginia University Campuses.

\section{Objectives of the Study}

To meet the above purposes, several objectives were developed:

- Describe student, faculty, and staff perception of dogs

- Describe how students, faculty, and staff interact with visitation and therapy dogs on campus

- Describe how students, faculty, and staff perceive their interaction with visitation and therapy dogs on campus

- Identify differences between students, faculty, and staff demographics and their perceptions of visitation and therapy dogs on campus

\section{Research Design}

This study utilized descriptive research techniques in the form of a survey generated online through Qualtrics®. The survey was accessed through a link emailed to university email addresses of all students, faculty, and staff at West Virginia University on campuses located in Morgantown, WV. The survey is designed to assess how students, faculty, and staff interact with visitation and therapy dogs on campus, where 
they interact with visitation and therapy dogs on campus, and how interactions are perceived by students, faculty, and staff.

\section{Significance of the Study}

This study is important to the students, faculty, and staff who might benefit from AAI. Additional information on how individuals perceive the use of visitation and therapy dogs on college campuses may help those practicing these methods improve the use, management, and training of dogs and handlers, ultimately improving the outcomes of those interacting with visitation and therapy dogs.

\section{Limitations and Assumptions of the Study}

The conclusions and implications drawn from this study are subject to the study's limitations, explored further below.

Generalization limitations. The data were limited to one university. Student demographics are less diverse at WVU when compared to other higher education institutions of similar size.

The following assumptions were made in order to conduct this study:

- Respondents in this study answered the questions to the best of their ability

- Respondents know that visitation and therapy dogs are on campus 


\section{CHAPTER 2}

\section{Review of Literature}

\section{Taxonomy of Assistance Animals}

Animal Assisted Interventions (AAI) is a term accepted by professionals in the field that includes both Animal Assisted Therapies (AAT) and Animal Assisted Activities (AAA; Borregoet al., 2014). For AAI to be considered AAT, an individual therapeutic objective must be incorporated, while AAA are interactions which focus on social, recreational, and educational aspects (Borrego et al.). Friesian (2009) identifies the issue of a lack of research differentiating between AAI and differentiating between the terms “therapy dog” and “visitation dog.” Parenti, Forman, Meade, and Wirth (2013) also address the confusion of labels given to assistance animals. They identify human uses of dogs in several categories, including companion dogs, hunting dogs, service dogs, visitation dogs, and therapy dogs (Parenti et al., 2013). Many animals used for AAI provide the same function but are given different titles; alternatively, sometimes animals used for AAI provide different functions and are given the same title. This creates inconsistency in government legislation and by practitioners of visitation and therapy dogs (Parenti et al., 2013). A dog being used for AAA is a visitation dog, providing a service in schools, hospitals, college campuses, and other similar environments for stress relief or social lubricant. A dog being used for AAT is a therapy dog. It is used as a tool to reach an individual therapeutic goal (Parenti et al., 2013; Borrego et al., 2014).

Although this study will be looking at the use of visitation dogs on college campuses, it is important to clarify that therapy dogs and visitation dogs are commonly confused both in literature and in practice. The health and social benefits of companion, visitation, therapy, 
and service dogs have been supported in previous research and are often generalized (Jalongo, Astroino, \& Bomboy 2004).

\section{Health and Social Benefits of Visitation and Therapy Dogs}

Psychologist Boris Levison (1984) is often considered the pioneer of AAT and AAA. In the 1960s, he found that dogs acted as a social lubricant between therapist and patient. Research following Levison's findings has provided empirical evidence of health and social benefits of AAI. Scozato et al. (2017) reported a significant improvement in attention to movement, visuomotor coordination, exploratory play, and motor imitation in adults with intellectual disabilities after AAT. This study also found that respondents who interacted with a dog displayed improved and coordination and basic social skills when participating in group activities compared to the control group (Scorzato et al., 2017).

Baun, Bergstorm, Langston, and Toma (1983) explored the physiological effects of petting dogs by measuring blood pressure and heart and respiration rates in 24 volunteer respondents. Respondents completed three tasks: quietly reading alone, petting an unfamiliar dog, and petting their own dog. Results showed a significant difference in all three tasks. Respondents' blood pressure and heart and respiration rates decreased when petting an unfamiliar dog compared to when reading alone. Furthermore, physiological measures decreased when petting their own dog compared to an unfamiliar dog (Baun et el, 1983). This study was limited by a small population and sampling bias (all respondents owned a dog). Results may have been different if respondents did not interact with dogs regularly or were fearful of dogs prior to participating. 
Muckle and Lasikiewicz (2017) explored the benefits of AAI on stress in college students, and found that AAA had a positive effect on psychological and physiological markers of stress, as well as on self-esteem. The reduction of perceived anxiety in students after participating in AAA was also an important finding of Muckle and Lasikiewicz (2017). Anderson and Olsen (2009) provided evidence that the presence of dogs can reduce depression, stress, homesickness, and feelings of isolation in a person or student. Research in primary and secondary schools has shown that therapy and visitation dogs lead to improved relationships among classmates and authority figures, decreased tantrums, increased eye contact, and decreased learned helplessness. (Granger et al., 1998; Zents, Fisk \& Lauback, 2017).

\section{Student Stress on College Campus}

Often, college students are put into new environments, separated from their families and other social networks, and forced to adjust to new living circumstances. Students undergo pressures to succeed in this new environment and need assistance with academic success and emotional balance (Jalongo \& McDevitt, 2015). Brougham, Zail, Mendoza and Miller (2009) found that factors of stress for college students include: financial, academic, family, and social circumstances. Lee, Dickson, Conley and Holmbeck (2014) found that transitioning into college allows students to become vulnerable to developing or exacerbating symptoms of depression. Picard (2015) states that because of stress, anxiety, and depressive symptoms in college students, it is important to assist them with finding ways for cope. Picard (2015) found that college students who interacted with dogs on campus showed a significant increase in mood.

\section{Studies Including AAI on College Campuses}


Muckles and Lasikiewicz's (2017) study explored the benefits of AAA in undergraduate students. Sixty-two undergraduates from National University and James Cook University in Singapore participated in AAA and were compared to a control group that participated in a quiet reading session. Psychological measures were used to determine attitudes toward animals, perceived stress, perceived anxiety, and self-esteem. Physiological measures were determined using systolic and diastolic blood pressure readings. Muckle and Lasikiewicz (2017) found that AAA had a positive effect on student's self-esteem and perceived anxiety. The reduction of perceived anxiety after AAA activities was significant compared to those who participated in quiet reading. Students with low self-esteem benefited the most from AAA. Muckle and Lasikiewicz (2017) discussed that since stress is often associated with feelings of helplessness and the loss of self-esteem, AAA may provide an excellent tool for college student stress reduction. In a similar study, Binfet (2017) looked at group-administered AAT on university students’ wellbeing. One hundred and sixty-three students in a first-year psychology class participated in this study. Students were given pre- and post-tests to determine demographics, perceived stress, and sense of belonging in school. Students participated in one of three separate intervention sessions each containing 50-60 students, 14 therapy dogs, and 14 handlers. Students who were randomly selected to participate in the treatment group showed a significant decrease in stress and homesickness over the previous month than the control group. Binfet (2017) also provided evidence that singlesession-AAT impacted respondents positively; however, this was not sustained over time, supporting the idea that multiple interactions with AAA are more useful to reach therapeutic and social goals. 
In a recent study, researchers investigated the prevalence of AAA on college campuses in the United States. In the study, researchers collected information from 68 schools and sought information such as prevalence, safety requirements, location, and perceptions of AAA on college campuses (Haggerty \& Mueller, 2017). Haggerty and Mueller (2017) found that AAA on college campuses is becoming more prevalent and recommended more exploration of this subject. Colleges surveyed showed a variety of inconsistencies in practice such as location of AAI and resources used to obtain dogs. Some colleges reported having dogs in dormitories, libraries, or outside (Haggerty \& Mueller 2017). Haggerty and Mueller (2017) suggest basic guidelines, including hand hygiene practices and keeping animals on a leash. Most importantly, this study concluded that higher education facilities would have more success with AAA if more information about visitation and therapy dogs was provided to those who will be in the presence of such dogs on campus (Haggerty \& Mueller, 2017).

\section{Perception Studies on AAI}

There are few perception studies regarding AAI. Most of the studies examined AAI in health care facilities, with one study examining AAI in an elementary school. Bibbo (2013) asked staff members at a health care facility about their perceptions of the implementation of AAA in their workplace. This study found that staff members who had a lot of interaction with dogs at their workplace agreed that AAA was significantly more beneficial than those surveyed who had little to no interaction with the dogs (Bibbo, 2012). One participant in this study commented that they felt AAA in health care facilities was inappropriate because some patients were afraid of dogs or too ill to participate; generally, however, the data supported positive perceptions of AAA in this 
health care facility (Bibbo, 2012). It was also found that the handler played a vital role in the acceptance of AAA (Bibbo, 2012). In other perception studies, it was discovered that staff were more likely to perceive AAA positively after an introduction of AAA when compared to the anticipation of AAA in a facility (Moody et al, 2002). Moody (2002) states that for AAA to be successful, staff members should be involved in the implementation and design of AAA.

Zents (2018) explored the perceptions of the use of dogs in four rural school districts in Western New York. A sample of both faculty and students were included; however, different interviews and surveys were given to the groups (Zents, 2017). Most students felt they had a close relationship to the dog and felt unconditional love, and faculty reported feeling that therapy dogs were either somewhat or very effective in helping students. This study was limited by a homogenous demographic (Zents, 2018). 


\section{CHAPTER 3}

\section{Methodology}

\section{Purpose of the Study}

This study was conducted with three core purposes. The first purpose was to explore how students, faculty, and staff perceive dogs in general. The second purpose sought to describe how students, faculty, and staff perceive visitation and therapy dogs on West Virginia University Campuses. The third purpose sought to determine if the diverse population on college campuses affects the perceptions of visitation and therapy dogs on West Virginia University Campuses.

\section{Objectives of the Study}

To meet the above purposes, several objectives were developed:

- Describe student, faculty, and staff perception of dogs

- Describe how students, faculty, and staff interact with visitation and therapy dogs on campus

- Describe how students, faculty, and staff perceive their interaction with visitation and therapy dogs on campus

- Identify differences between students, faculty, and staff demographics and their perceptions of visitation and therapy dogs on campus

\section{Research Design}

This study utilized descriptive research techniques in the form of a survey generated online through Qualtrics ${ }^{\circledR}$. The survey was accessed through a link emailed to university email addresses of all students, faculty, and staff at West Virginia University on campuses located in Morgantown, WV. The survey was designed to assess how 
students, faculty, and staff interact with visitation and therapy dogs on campus, where they interact with visitation and therapy dogs on campus, and how interactions are perceived by students, faculty, and staff.

\section{Population}

The target population of this study consists of all students, faculty, and staff at West Virginia University located in Morgantown, WV. Students, faculty, and staff who are not located in Morgantown, WV were not included in this research. Students, faculty, and staff who only work with the university online were also excluded due to the focus on the use of visitation and therapy dogs on college campuses. All students, faculty, and staff of West Virginia University are provided with a university email intended to be the primary form of communication for the university. The accessible population included 43,119 students, faculty, and staff. A census was used of all students, faculty, and staff on West Virginia University Campuses located in Morgantown, WV.

\section{Instrumentation}

A survey was constructed including Likert-type questions addressing the subject of visitation and therapy dogs on campus. The survey was implemented through Qualtrics ${ }^{\circledR}$ servers and software and accessed via a link sent to each respondent via email. Likert-style questions regarding the interactions and perceptions of visitation and therapy dogs on campus were used. The instrument contained questions designed to provide insight into respondents' point of view on several predetermined constructs in the following order: general perceptions of dogs, perceived knowledge of the terms visitation

dog, therapy dog, and service dog, perceptions of having visitation and therapy dogs on campus, and perceptions of interactions with visitation and therapy dogs on campus. 
Non-response bias was addressed by comparing early and late respondents (Miller \& Smith, 1983). An independent t-test was conducted on all of the following constructs using SSPS statistical analysis software: general perceptions of dogs, perceptions of having visitation and therapy dogs on campus, and perceptions of interactions with visitation and therapy dogs on campus. There was a statistical difference between early and late respondents so all recommendations are generalizations of the respondents.

\section{Questions}

The first construct identified general perceptions of dogs. These questions sought to identify how respondents generally felt about dogs. This construct identified if respondents have ever had bad experiences with dogs and if they were fearful of dogs. Additionally, this construct identified if respondents felt dogs were comparable to family members and if they liked petting dogs.

The second construct asked questions to indicate respondents’ perceptions of having visitation or therapy dogs on campus. These questions addressed whether respondents felt that visitation and therapy dogs have the potential to benefit students. Questions also identified if respondents felt visitation and therapy dogs were good for WVU campuses.

The third construct sought to identify perceptions of interactions with visitation and therapy dogs on campus. Questions identified if respondents felt joy, stress relief, fear, or annoyances due to visitation and therapy dogs. This construct also identified how respondents perceived the behavior of the dogs and perceptions of how dogs were being handled or managed. 
In addition to the three constructs above, questions were asked to determine the frequency that respondents saw, heard, or interacted with visitation and therapy dogs on campus. Questions were also asked to identify how respondents perceived their knowledge of the terms visitation dog, therapy dog, and service dog. These questions did not identify if respondents knew the terms correctly; the questions only identified if the respondents thought they knew the definition of the terms. Demographic questions were also included in the survey, including questions about dog allergies, dog ownership, and proximity to dogs in the home.

\section{Validity and Reliability}

An instrument is said to have face validity if it appears to measure what it is intended to measure (Field, 2013). The survey instrument was determined to have content and face validity by a panel of experts consisting of University educators and an animal behavior consultant/assistant dog training specialist. Reliability was determined using a split-half test. Using the Spearman-Brown formula, correlation can be statistically corrected to estimate reliability. The final data set was used in the procedures. A Spearman-Brown coefficient was calculated for four constructs within the instrument.

For general feelings of having visitation and therapy dogs on campus, the survey instrument was found to have extensive reliability. For the construct perceptions of interactions with visitation and therapy dogs on WVU campuses, the survey instrument was found to have exemplary reliability (Robinson, Shaver, \& Wrightsman, 1991) (see Table 1). 
Table 1

Reliability of Major Parts of Instrument

\begin{tabular}{lll}
\hline Construct & $\begin{array}{c}\text { Cronbach’s } \\
\text { Alpha }\end{array}$ & $\begin{array}{c}\text { Robinson } \\
\text { Reliability }\end{array}$ \\
\hline $\begin{array}{l}\text { General feelings of having visitation or therapy } \\
\text { dogs on campus }\end{array}$ & .786 & Extensive \\
$\begin{array}{l}\text { Perceptions of visitation and therapy dogs on } \\
\text { WVU campuses }\end{array}$ & .877 & Exemplary \\
\hline
\end{tabular}

Procedures were taken to avoid various errors in research. Frame errors were avoided by using a census of students, faculty, and staff at West Virginia University campuses in Morgantown, WV. Sampling errors were avoided by taking a census of the entire population provided. Selection errors were avoided by receiving the official list of all emails belonging to students, faculty, and staff at West Virginia University campuses located in Morgantown, WV. If a census is not reached, one potential threat to external validity is non-response error. The use of a valid and reliable instrument ensured that a measurement error was avoided

\section{Data Collection Procedures}

This survey was distributed using Dillman’s Tailored Design Method. This method calls for an initial email to let respondents know they have been chosen for a research project, gives them information about the project, and asks that if they wish to participate to await future correspondence (Dillman, 2008). A cover letter (see Appendix I) and Qualtrics ${ }^{\circledR}$ survey link was sent via email to the population on April 5, 2018. The cover letter explained the purpose of the study and ensured confidentiality. Non- 
respondents received follow-up emails on April 10, 2018, April 16, 2018, and on April 23, 2018 (see Appendix II) The reminder email was sent on May 1, 2018 (see Appendix III). The last responses were recorded on May 10, 2018.

\section{Potential Impact}

The information gained from this survey will allow those using AAI on college campuses to identify perceived successes and problems with current use of AAI and provide recommendations for improving current practices. This survey will additionally provide a more accurate data set for future research. 


\section{CHAPTER 4}

\section{Findings}

\section{Purpose of Study}

This study was conducted with three core purposes. The first purpose was to explore how students, faculty, and staff perceive dogs in general. The second purpose sought to describe how students, faculty, and staff perceive visitation and therapy dogs on West Virginia University Campuses. The third purpose sought to determine if the diverse population on college campuses affects the perceptions of visitation and therapy dogs on West Virginia University Campuses.

\section{Objectives of the Study}

In order to meet the above purposes, several objectives were developed:

- Describe student, faculty, and staff perception of dogs

- Describe how students, faculty, and staff interact with visitation and therapy dogs on campus

- Describe how students, faculty, and staff perceive their interaction with visitation and therapy dogs on campus

- Identify differences between students, faculty, and staff demographics and their perceptions of visitation and therapy dogs on campus

\section{Demographics}

To describe the respondents, several demographic questions were analyzed.

Respondents were asked to identify if they considered themselves a student, faculty, or staff member at West Virginia University. Most respondents were students, indicated by 
respondents totaling 2,464 (60.41 \%). 527 (12.90\%) indicated faculty and 1,090 (26.69\%) indicated staff member (see Table 2).

Table 2

Student, Faculty, or Staff Member Demographics

\begin{tabular}{lcc}
\hline & $f$ & $\%$ \\
\hline Student & 2467 & 60.41 \\
Faculty & 527 & 12.90 \\
Staff & 1090 & 26.69 \\
\hline
\end{tabular}

Note. $n=4084$

Respondents were asked to select their gender as male, female, or not listed.

There were 1,371 male respondents (33.60\%) and 2,680 female respondents (65.69\%).

Twenty-nine respondents (.71\%) indicated their gender as not listed (see Table 3).

Table 3

Gender Demographics

\begin{tabular}{lcc}
\hline & $f$ & $\%$ \\
\hline Male & 1371 & 33.60 \\
Female & 2680 & 65.69 \\
Not Listed & 29 & .71 \\
\hline
\end{tabular}

Note. $n=4080$

Respondents were asked whether or not they identified as an international student, international faculty member, or international staff member. One hundred and eightyeight respondents (4.61\%) indicated yes and 3,886 respondents (95.39) indicated no (see Table 4). 
Table 4

International Student, International Faculty, International Staff Demographics

\begin{tabular}{lcc}
\hline & $f$ & $\%$ \\
\hline Yes & 188 & 4.61 \\
No & 3886 & 95.39 \\
\hline
\end{tabular}

Note. $n=4074$

Respondents were asked to identify their race. A clear majority indicated they were white with 3,719 respondents (91.49\%), 100 respondents (2.46\%) indicated black or African American, ten respondents (.25\%) selected American or Alaskan Native, 103 respondents (5.53\%) indicated Asian, five respondents (.12\%) indicated Pacific Islander, and 128 respondents (3.15\%) indicated other (see Table 5). There were 128 respondents (3.25\%) who identified being Hispanic and 3,812 respondents (96.75 \%) who indicated being non-Hispanic (see Table 6).

Table 5

Ethnicity Demographics

\begin{tabular}{lcc}
\hline & $f$ & $\%$ \\
\hline White & 3719 & 91.49 \\
Black or African American & 100 & 2.46 \\
American Indian or & 10 & .25 \\
Alaskan Native & 103 & 5.53 \\
Asian & 5 & .12 \\
Pacific Islander & 128 & 3.15 \\
Other & & \\
\hline
\end{tabular}

Note. $n=4065$ 
Table 6

Hispanic or Non-Hispanic

\begin{tabular}{lcc}
\hline & $f$ & $\%$ \\
\hline Hispanic & 128 & 3.25 \\
Non-Hispanic & 3812 & 96.75 \\
\hline
\end{tabular}

Note. $n=3940$

Respondents were asked to identify the area they grew up in as either suburban, rural, or urban. There were 1,954 respondents (41.27\%) who selected suburban, 434 respondents (10.67\%) who selected urban, and rural was selected by 1,678 respondents (41.27\%) (see Table 7).

Table 7

Suburban, Rural or Urban

\begin{tabular}{lcc}
\hline & $f$ & $\%$ \\
\hline Suburban & 1954 & 48.06 \\
Urban & 434 & 10.67 \\
Rural & 1678 & 41.27 \\
\hline
\end{tabular}

Note. $n=4066$

Respondents were asked to select their age range. Just over half were 18-24 years old (2,079 respondents; 50.99\%). There were 610 (14.98\%) who selected 25-30 years old, 418 (10.27\%) who selected 35-44 years old, 451 respondents (11.08\%) who selected 45-54 years old, 508 (12.48\%) who selected 55-74 years old, and eight (0.20\%) respondents who selected 75 years old or older (see Table 8). 
Table 8

Respondent Age Range

\begin{tabular}{lcc}
\hline & $f$ & $\%$ \\
\hline 18-24 years old & 2076 & 50.99 \\
25-34 years old & 610 & 14.98 \\
35-44 years old & 418 & 10.27 \\
$45-54$ years old & 451 & 11.08 \\
$55-74$ years old & 508 & 12.48 \\
75 years or older & 8 & .20 \\
\hline
\end{tabular}

Note. $n=4062$

Additional questions were asked to better understand the respondents’ experiences with dogs. Most respondents (55.55\%) indicated they currently own a dog. An overwhelming majority (90.14\%) indicated that they have lived in the same household as a dog. Only 8.1\% indicated they were allergic to dogs (see Table 9).

Table 9

Respondents' History with Dogs in General

\begin{tabular}{|c|c|c|c|c|}
\hline & \multicolumn{2}{|c|}{ Yes } & \multicolumn{2}{|c|}{ No } \\
\hline & $f$ & $\%$ & $f$ & $\%$ \\
\hline Do you currently own a dog? ${ }^{\mathrm{a}}$ & 2264 & 55.54 & 1812 & 44.46 \\
\hline $\begin{array}{l}\text { Have you ever lived in the same household } \\
\text { as a dog? }\end{array}$ & 3684 & 90.14 & 403 & 9.86 \\
\hline Are you allergic to dogs? ${ }^{c}$ & 327 & 8.01 & 3756 & 91.99 \\
\hline
\end{tabular}

Note. ${ }^{\mathrm{a}} n=4076^{\mathrm{b}} n=4087^{\mathrm{c}} n=4083$ 


\section{General Perceptions of Dogs}

Students, faculty, and staff were asked to identify their general perceptions of dogs. For the statement, “I generally like dogs,” 3702 respondents (81.38\%) selected strongly agree, 643 respondents selected agree, 125 respondents (2.75\%) selected disagree and 79 respondents (1.74\%) selected strongly disagree. For the statement "When I hear a dog bark on campus I avoid it,” 245 respondents (5.41\%) strongly agreed, 998 respondents (22.04\%) agreed, 2,066 respondents (45.63\%) disagreed and 1,219 respondents (26.92\%) strongly disagreed. 71 respondents (1.57\%) selected strongly agree and 120 respondents (2.65\%) selected agree to the statement "I am afraid of dogs;" however, the majority of respondents selected either disagree (1,180 respondents; 26.01\%) or strongly disagree (3,165 respondents; 69.78\%). For the statement "I am afraid of dogs I do not know,” there were 123 respondents (2.71\%) who strongly agreed, and 480 respondents (10.56) who agreed. Most respondents selected either disagree $(1,993 ; 43.85 \%)$ or strongly disagree $(1,949 ; 42.88 \%)$. When presented with the statement “Dogs increase the risk of disease,” 106 respondents (2.34\%) selected strongly agree, 308 respondents (6.79\%) selected agree, 1,638 respondents (36.14\%) selected disagree, and 2,481 respondents (54.73\%) selected strongly disagree. When presented with the statement "I find dogs to be unclean,” there were 110 respondents $(2.43 \%)$ who selected strongly agree, 435 respondents (9.59\%) who selected agree, 1,715 respondents (37.81\%) who selected disagree, and 2,276 respondents (50.18\%) who selected strongly disagree. For the statement "people should be allowed to bring their dogs to work," 1,628 respondents (35.97\%) strongly agreed, 1,323 respondents (29.23\%) agreed, 1,111 respondents (24.55\%) disagreed, and 464 respondents (10.25) strongly disagreed. For the 
statement "people should be allowed to bring their dogs anywhere," 1,232 respondents (27.18\%) strongly agreed, 952 respondents (21.01\%) agreed, 1,688 respondents (37.25\%) disagreed and 660 respondents (14.56\%) strongly disagreed. For the statement "dogs can reduce stress for people,” 3,273 respondents (72.09\%) strongly agreed, 1,136 respondents (25.02\%) agreed, 88 respondents (1.94\%) disagreed, and 43 respondents (.95\%) strongly disagreed. There were 2,575 respondents (56.88\%) who stated selected strongly agree, 1,256 respondents (27.94\%) who selected agree, 537 respondents (11.86\%) who selected disagree and 159 respondents (3.51\%) who selected strongly disagree to the statement "Dogs increase the risk of disease". When presented with the statement "Dogs make me happy,” there were 3,226 respondents (71.17\%) who stated selected strongly agree, 987 respondents (21.77\%) who selected agree, 221 respondents (4.88\%) who selected disagree, and 99 respondents (2.18\%) who selected strongly disagree. . When presented with the statement “ I like petting dogs,” 33,10 respondents (72.96\%) stated selected strongly agree, 931 respondents (20.52\%) selected agree, 197 respondents (4.34\%) selected disagree, and 99 respondents (2.18\%) selected strongly disagree. For the statement "I consider dogs as family members," there were 3,169 respondents (70.00\%) who strongly agreed, 919 respondents (20.30\%) who agreed, 287 respondents (6.94\%) who disagreed, and 152 respondents (3.36\%) who strongly disagreed. For the statement "I have had a bad experience involving a dog," there were 344 respondents (7.59\%) who strongly agreed, 1070 respondents (23.60\%) who agreed, 12.16 respondents (26.83\%) who disagreed, and 1903 respondents (41.98\%) who strongly disagreed. For the statement "I have had a good experience involving a dog” there were 3,561 respondents (78.51\%) who strongly agreed, 827 respondents (18.23\%) who agreed, 89 respondents 
(1.96\%) who disagreed, and 59 respondents (1.30\%) who strongly disagreed (see Table $10)$. 
Table 10

General Perceptions of Dogs

\begin{tabular}{|c|c|c|c|c|c|c|c|c|}
\hline & \multicolumn{2}{|c|}{ Strongly Agree } & \multicolumn{2}{|c|}{ Agree } & \multicolumn{2}{|c|}{ Disagree } & \multicolumn{2}{|c|}{ Strongly disagree } \\
\hline & $f$ & $\%$ & $f$ & $\%$ & $f$ & $\%$ & $f$ & $\%$ \\
\hline I generally like dogs. & 3702 & 81.38 & 643 & 14.13 & 125 & 2.75 & 79 & 1.74 \\
\hline When I hear dogs bark I will avoid it. & 245 & 5.41 & 998 & 22.04 & 2066 & 45.63 & 1219 & 26.92 \\
\hline I am afraid of dogs. & 71 & 10.57 & 120 & 2.65 & 1180 & 26.01 & 3165 & 69.78 \\
\hline I am afraid of dogs I do not know. & 123 & 2.71 & 480 & 10.56 & 1993 & 43.85 & 1949 & 42.88 \\
\hline I am not afraid of dogs if I trust their owner. & 210 & 4.63 & 523 & 11.54 & 1833 & 40.45 & 1965 & 43.37 \\
\hline Dogs increase the risk of disease. & 106 & 2.34 & 304 & 2.79 & 1638 & 36.14 & 2481 & 54.73 \\
\hline I find dogs to be unclean. & 110 & 2.43 & 435 & 9.59 & 1715 & 37.81 & 2276 & 50.18 \\
\hline $\begin{array}{l}\text { People should be allowed to bring their dogs to } \\
\text { work. }\end{array}$ & 1628 & 35.97 & $\begin{array}{l}132 \\
3\end{array}$ & 29.23 & 1111 & 24.55 & 464 & 10.25 \\
\hline $\begin{array}{l}\text { People should be allowed to bring their dogs } \\
\text { anywhere. }\end{array}$ & 1232 & 27.18 & 952 & 21.01 & 1688 & 37.25 & 660 & 14.56 \\
\hline Dogs can reduce stress for people. & 3273 & 72.09 & 1136 & 25.02 & 88 & 1.94 & 43 & .95 \\
\hline Dogs make me feel secure. & 2575 & 56.88 & 1256 & 27.74 & 537 & 11.86 & 159 & 3.51 \\
\hline
\end{tabular}

Note. $n=4082$ 
Table 10

General Perceptions of Dogs Continued

\begin{tabular}{|c|c|c|c|c|c|c|c|c|}
\hline & \multicolumn{2}{|c|}{ Strongly Agree } & \multicolumn{2}{|c|}{ Agree } & \multicolumn{2}{|c|}{ Disagree } & \multicolumn{2}{|c|}{ Strongly Disagree } \\
\hline & $f$ & $\%$ & $f$ & $\%$ & $f$ & $\%$ & $f$ & $\%$ \\
\hline Dogs make me happy. & 3226 & 71.17 & 987 & 21.77 & 221 & 4.88 & 99 & 2.18 \\
\hline I like petting dogs. & 3310 & 72.96 & 931 & 20.52 & 197 & 4.34 & 99 & 2.18 \\
\hline I consider dogs as family members. & 3169 & 70.00 & 919 & 20.30 & 287 & 6.34 & 152 & 3.36 \\
\hline I have had a bad experience involving a dog. & 344 & 7.59 & 1216 & 26.83 & 1070 & 23.60 & 1903 & 41.98 \\
\hline I have had a good experience with a dog. & 3561 & 78.51 & 86 & 1.96 & 827 & 18.23 & 59 & 1.30 \\
\hline
\end{tabular}

Note. $n=4082$ 
Respondents were asked to indicate their perceived knowledge of the terms “service dog,” “visitation dog,” and “therapy dog” using a four-point Likert scale. Answer options were strongly agree, agree, disagree, or strongly disagree. 2,916 respondents (70.86\%) strongly agreed, 1,130 respondents (27.46 \%) who agreed, 62 respondents (1.51) who disagreed, and seven respondents (.17\%) who strongly disagreed to the statement "I know what a service dog is." There were 1,693 respondents (41\%) who strongly agreed, 1,186 (28.89\%) who agreed, 1,120 respondents (27.28\%) who disagreed, and 106 (2.50\%) who strongly disagreed with the statement "I know what a visitation dog is.” To the statement “I know what a therapy dog is,” 2,518 respondents (61.35\%) selected strongly agree, 1,402 (34.16\%) selected agree, 166 (4.04\%) selected disagree, and eighteen respondents (.44\%) selected strongly disagree (see Table 11).

Table 11

Perceived Knowledge of Terms

\begin{tabular}{|c|c|c|c|c|c|c|c|c|}
\hline & \multicolumn{2}{|c|}{$\begin{array}{c}\text { Strongly } \\
\text { Agree }\end{array}$} & \multicolumn{2}{|c|}{ Agree } & \multicolumn{2}{|c|}{ Disagree } & \multicolumn{2}{|c|}{$\begin{array}{l}\text { Strongly } \\
\text { Disagree }\end{array}$} \\
\hline & $f$ & $\%$ & $f$ & $\%$ & $f$ & $\%$ & $f$ & $\%$ \\
\hline $\begin{array}{l}\text { I know what a } \\
\text { service dog is. }\end{array}$ & 2916 & 70.86 & 1130 & 27.46 & 62 & 1.51 & 7 & .17 \\
\hline $\begin{array}{l}\text { I know what a } \\
\text { visitation dog is. }\end{array}$ & 1693 & 41.24 & 1186 & 28.89 & 1120 & 27.28 & 106 & 2.58 \\
\hline $\begin{array}{l}\text { I know what a } \\
\text { therapy dog is. }\end{array}$ & 2518 & 61.35 & 1402 & 34.16 & 166 & 4.04 & 18 & .44 \\
\hline
\end{tabular}

Respondents were asked a series of Likert-type questions to identify how they felt about the presence of visitation and therapy dogs on campus. When presented with the statement "The presence of visitation and therapy dogs are good for WVU campuses," 2,708 respondents (66.88\%) selected strongly agree, 1,014 (25\%) selected agree, 226 
(5.58\%) selected disagree, and 101 respondents (2.49\%) selected strongly disagree. . For the statement "I am more likely to talk to a person if they are handling a visitation or therapy dog,” 1,790 respondents (44.08\%) selected strongly agree, 1,110 (27.33\%) selected agree, 886 (21.82) selected disagree, and 275 (6.77\%) selected strongly disagree. When presented with the statement "I would like to see more Visitation or Therapy dogs on campus,” 2,480 respondents selected strongly agree, 1,003 respondents (24.94 \%) selected agree, 400 (9.95\%) selected disagree, and 211 respondents (5.25\%) who selected strongly disagree. When presented with the statement "I am afraid of therapy and visitation dogs on campus,” 55 respondents (1.36\%) selected strongly agree, 71 (1.75\%) selected agree, 840 (20.72) selected disagree, and 3,089 respondents who selected strongly disagree. For the statement "I am more likely to go to an office if a visitation or therapy dog is there,” 1,705 respondents (42.02\%) selected strongly agree, 1,036 (25.53) selected agree, 910 (22.42\%) selected disagree, and 407 (10.03\%) selected strongly disagree (see Table 12). 
Table 12

Perceptions of Having Visitation or Therapy Dogs on Campus

\begin{tabular}{|c|c|c|c|c|c|c|c|c|}
\hline & \multicolumn{2}{|c|}{$\begin{array}{l}\text { Strongly } \\
\text { Agree }\end{array}$} & \multicolumn{2}{|c|}{ Agree } & \multicolumn{2}{|c|}{ Disagree } & \multicolumn{2}{|c|}{$\begin{array}{l}\text { Strongly } \\
\text { Disagree }\end{array}$} \\
\hline & $f$ & $\%$ & $f$ & $\%$ & $f$ & $\%$ & $f$ & $\%$ \\
\hline $\begin{array}{l}\text { The presence of visitation and } \\
\text { therapy dogs are good for WVU } \\
\text { campuses. }\end{array}$ & 2708 & 66.88 & 1014 & 25.04 & 226 & 5.58 & 101 & 2.49 \\
\hline $\begin{array}{l}\text { I am more likely to talk to a person if } \\
\text { they are handling a visitation or } \\
\text { therapy dog. }\end{array}$ & 1790 & 44.08 & 1110 & 27.33 & 886 & 21.82 & 275 & 6.77 \\
\hline $\begin{array}{l}\text { I would like to see more visitation or } \\
\text { therapy dogs on campus. }\end{array}$ & 2408 & 59.87 & 1003 & 24.94 & 400 & 9.95 & 211 & 5.25 \\
\hline $\begin{array}{l}\text { I am afraid of therapy and visitation } \\
\text { dogs on campus. }\end{array}$ & 55 & 1.36 & 71 & 1.75 & 840 & 20.72 & 3089 & 76.18 \\
\hline $\begin{array}{l}\text { I am more likely to go to an office if } \\
\text { a visitation or therapy dog is there. }\end{array}$ & 1705 & 42.02 & 1036 & 25.53 & 910 & 22.42 & 407 & 10.03 \\
\hline
\end{tabular}


Respondents were asked to indicate the frequency with which they interacted with visitation and therapy dogs on campus. They could choose almost every day, two to three times a week, once a week, once or twice a month, once a semester or never for each question. When presented with the item "How often do you see visitation or therapy dogs on campus?” there were 459 respondents (11.34\%) who selected every day, 730 (18\%) who selected two to three times a week, 667 (16.49\%) who selected once a week, 861 (21.28\%) who selected once or twice a month, 695 (17.18\%) who selected once a semester, and 632 respondents who selected never to the question. To the question "how often do you see visitation or therapy dogs on campus?” there were 142 respondents (3.53\%) who selected every day, 292 (7.27\%) who selected two to three times a week, 392 (9.75 \%) who selected once a week, 603 (15.00\%) who selected once or twice a month, 569 (14.16\%) who selected once a semester, and 2,021 respondents (50.29\%) who selected never . To the question "How often do you interact with visitation or therapy dogs on campus?” there were 153 respondents (3.82\%) who selected every day, $300(7.49 \%)$ who selected two to three times a week, 422 (10.53 \%) who selected once a week, 800 (20.16\%) who selected once or twice a month, 900 (22.64\%) who selected once a semester, and 1,424 respondents (35.54\%) who selected never. To the question "How often do you intentionally seek out a visitation or therapy dog on campus?" there were 151 respondents (3.77\%) who selected every day, 127 (3.17\%) who selected two to three times a week, 209 (5.22 \%) who selected once a week, 3.29 (8.21\%) who selected once or twice a month, 428 (10.69\%) who selected once a semester, and 2,061 respondents (68.94\%) who selected never. (see Table 13). 
Table 13

Frequency of Interactions of Students, Faculty, and Staff with Visitation and Therapy Dogs on Campus

\begin{tabular}{|c|c|c|c|c|c|c|c|c|c|c|c|c|}
\hline & \multicolumn{2}{|c|}{$\begin{array}{c}\text { Almost Every } \\
\text { day }\end{array}$} & \multicolumn{2}{|c|}{$\begin{array}{c}\text { Two to } \\
\text { Three times } \\
\text { a week }\end{array}$} & \multicolumn{2}{|c|}{ Once a week } & \multicolumn{2}{|c|}{$\begin{array}{l}\text { Once or } \\
\text { twice a } \\
\text { month }\end{array}$} & \multicolumn{2}{|c|}{$\begin{array}{c}\text { Once a } \\
\text { Semester }\end{array}$} & \multicolumn{2}{|c|}{ Never } \\
\hline & $f$ & $\%$ & $f$ & $\%$ & $f$ & $\%$ & $f$ & $\%$ & $f$ & $\%$ & $f$ & $\%$ \\
\hline $\begin{array}{l}\text { How often do you see } \\
\text { visitation or therapy dogs on } \\
\text { campus? }\end{array}$ & 459 & 11.34 & 730 & 18.04 & 667 & 16.49 & 861 & 21.28 & 695 & 17.18 & 634 & 15.67 \\
\hline $\begin{array}{l}\text { How often do you hear (i.e. } \\
\text { barking, tags jingling, etc.) } \\
\text { visitation or therapy dogs on } \\
\text { campus? }\end{array}$ & 142 & 3.53 & 292 & 7.27 & 392 & 9.75 & 603 & 15.00 & 569 & 14.16 & 2021 & 50.29 \\
\hline $\begin{array}{l}\text { How often do you interact } \\
\text { with visitation or therapy } \\
\text { dogs? }\end{array}$ & 1153 & 3.82 & 300 & 7.49 & 422 & 10.53 & 808 & 20.16 & 900 & 22.46 & 1424 & 35.54 \\
\hline $\begin{array}{l}\text { How often do you } \\
\text { intentionally seek out a } \\
\text { visitation or therapy dog on } \\
\text { campus? }\end{array}$ & 151 & 3.77 & 127 & 3.17 & 209 & 5.22 & 329 & 8.21 & 428 & 10.69 & 2761 & 68.94 \\
\hline
\end{tabular}

Note. $n=4046$ 
Respondents were asked to indicate how they perceived their interactions with visitation or therapy dogs on campus. A majority of respondents agreed (31.98\%) or strongly agreed (38.96\%) that they have personally benefited from a visitation or therapy dog on campus, while 451 respondents (18.26\%) selected disagree and 242 (9.80\%) selected strongly disagree. In response to the statement "I have avoided an area on campus because visitation or therapy dogs were present,” there were 79 (2.13\%A) who selected strongly agree, 129 (3.62\%) who selected agree, 577 (16.20\%) who selected disagree, and 2,780 respondents (78.05\%) who selected strongly disagree. In response to the statement "visitation or therapy dogs have created stress in my work and/or learning environment,” there were 104 (3.00\%) respondents who selected strongly agree, 179 (5.17\%) who selected agree, 568 (16.39\%) who selected disagree, and 2,614 (75.44\%) who selected strongly disagree. For the statement "I have seen visitation and therapy dogs on campus without a leash,” there were 347 (10.03\%) respondents who selected strongly agree, 630 (18.22\%) who selected agree, 860 (24.87\%) who selected disagree, and 1,621 (46.88\%) who selected strongly disagree. In response to the statement "I have been uncomfortable because of a visitation or therapy dog on campus” there were 84 (2.31\%) respondents who selected strongly agree, 139 (3.82) who selected agree, 587 (16.11\%) who selected disagree, and 2,833 (77.77\%) who selected strongly disagree. In response to the statement "I have attended a campus event because I knew a visitation or therapy dog would be there,” there were 797 (29.77\%) respondents who selected strongly agree, 543 (20.28\%) who selected agree, 702 (26.22\%) who selected disagree, and 635 (23.72\%) who selected strongly disagree. For the statement "I would attend more campus events if I knew visitation or therapy dogs were there,” there were 1,401 (40.39\%) 
respondents who selected strongly agree, 900 (25.89\%) who selected agree, 640 (18.41\%) who selected disagree, and 532 (15.30\%) who selected strongly disagree. In response to the statement "I am less stressed after being around a visitation or therapy dog on campus,” there were 1,679 (49.70\%) respondents who selected strongly agree, 1,034 (30.61\%) who selected agree, 375 (11.10\%) who selected disagree, and 290 (8.58\%) who selected strongly disagree. In response to the statement "I have been unable to tell if a dog is a pet or visitation or therapy on campus," there were 87 respondents (2.45\%) who selected strongly agree, 195 (5.49\%) who selected agree, 741 (20.86\%) who selected disagree, and 2,529 (71.20\%) who selected strongly disagree. In response to the statement "I have been uncomfortable because a visitation or therapy dog was off leash on campus,” there were 62 (1.85\%) respondents who selected strongly agree, 94 (2.81\%) who selected agree, 626 (18.73\%) who selected disagree, and 2,561 (76.61\%) who selected strongly disagree (see Table 14). 
Table 14

Perceptions of Interactions with Visitation and Therapy Dogs on Campus

\begin{tabular}{|c|c|c|c|c|c|c|c|c|}
\hline & \multicolumn{2}{|c|}{ Strongly Agree } & \multicolumn{2}{|c|}{ Agree } & \multicolumn{2}{|c|}{ Disagree } & \multicolumn{2}{|c|}{ Strongly Disagree } \\
\hline & $f$ & $\%$ & $f$ & $\%$ & $f$ & $\%$ & $f$ & $\%$ \\
\hline $\begin{array}{l}\text { I have personally benefited from a visitation or } \\
\text { therapy dog on campus. }\end{array}$ & 987 & 39.96 & 790 & 31.98 & 451 & 18.26 & 242 & 9.80 \\
\hline $\begin{array}{l}\text { I have avoided an area on campus because } \\
\text { visitation or therapy dogs were present. }\end{array}$ & 76 & 2.13 & 129 & 3.62 & 577 & 16.20 & 2780 & 78.05 \\
\hline $\begin{array}{l}\text { Visitation or therapy dogs have created stress } \\
\text { in my work and/or learning environment. }\end{array}$ & 104 & 3.00 & 179 & 5.17 & 568 & 16.39 & 2614 & 75.44 \\
\hline $\begin{array}{l}\text { I have seen visitation and therapy dogs on } \\
\text { campus without a leash. }\end{array}$ & 347 & 10.03 & 630 & 18.22 & 860 & 24.87 & 1621 & 46.88 \\
\hline $\begin{array}{l}\text { I have been uncomfortable because of a } \\
\text { visitation or therapy dog on campus. }\end{array}$ & 84 & 2.31 & 139 & 3.82 & 587 & 16.11 & 2833 & 77.77 \\
\hline I have attended a campus event because I & & & & & & & & \\
\hline $\begin{array}{l}\text { knew a visitation or therapy dog would be } \\
\text { there. }\end{array}$ & 797 & 29.77 & 543 & 20.28 & 702 & 26.22 & 635 & 23.72 \\
\hline $\begin{array}{l}\text { I would attend more campus events if I knew } \\
\text { visitation or therapy dogs were there. }\end{array}$ & 1404 & 40.39 & 900 & 25.89 & 640 & 18.41 & 532 & 15.30 \\
\hline
\end{tabular}

Note. $n=4920$ 
Table 14

Perceptions of Interactions with Visitation and Therapy Dogs on Campus Continued

\begin{tabular}{|c|c|c|c|c|c|c|c|c|}
\hline & \multicolumn{2}{|c|}{ Strongly Agree } & \multicolumn{2}{|c|}{ Agree } & \multicolumn{2}{|c|}{ Disagree } & \multicolumn{2}{|c|}{$\begin{array}{l}\text { Strongly } \\
\text { Disagree }\end{array}$} \\
\hline & $f$ & $\%$ & $f$ & $\%$ & $f$ & $\%$ & $f$ & $\%$ \\
\hline $\begin{array}{l}\text { I am less stressed after being around a visitation or } \\
\text { therapy dog on campus. }\end{array}$ & 1679 & 49.70 & 1034 & 30.61 & 375 & 11.10 & 290 & 8.58 \\
\hline $\begin{array}{l}\text { I have had a negative experience with a visitation or } \\
\text { therapy dog on campus. }\end{array}$ & 64 & 1.86 & 87 & 2.52 & 553 & 16.05 & 2742 & 79.57 \\
\hline $\begin{array}{l}\text { I have been unable to tell if a dog is a pet or } \\
\text { visitation or therapy on campus. }\end{array}$ & 263 & 7.54 & 752 & 21.57 & 1037 & 29.75 & 1434 & 41.14 \\
\hline $\begin{array}{l}\text { I have seen a visitation or therapy dog behave badly } \\
\text { on campus (i.e.: barking, jumping, or being } \\
\text { disruptive). }\end{array}$ & 87 & 2.45 & 195 & 5.49 & 741 & 20.86 & 2529 & 71.20 \\
\hline $\begin{array}{l}\text { I have been uncomfortable because a visitation or } \\
\text { therapy dog was off leash on campus }\end{array}$ & 62 & 1.85 & 94 & 2.81 & 626 & 18.73 & 2561 & 76.61 \\
\hline
\end{tabular}

Note. $n=4920$ 
Means were calculated for the following data sets: General perceptions of dogs, perceived knowledge of dogs, general perceptions of dogs on campus, and perceptions of interactions with visitation and therapy dogs on campus. The mean for general perceptions of dogs was $1.38(\mathrm{SD}=.45)$, indicating that respondents' general perceptions of dogs were positive with a scale of 1-1.5 as strongly agree, 1.6-2.5 as agree 2.6-3.5 as disagree and 3.6-4.0 as strongly disagree (see Table 15). The mean for the perceived knowledge of terms had a mean of $1.55(\mathrm{SD}=.55)$. General perceptions of dogs on campus had a mean of $1.65(\mathrm{SD}=.69)$, indicating that respondents viewed this construct positively. The mean for the perceptions of interactions with dogs on campus was 1.94 $(\mathrm{SD}=.48)$ (see Table 15).

Table 15

Means of Data Sets

\begin{tabular}{|c|c|c|}
\hline & $\mathrm{M}$ & SD \\
\hline General Perceptions of Dogs ${ }^{a}$ & 1.83 & .43 \\
\hline Perceived Knowledge of Terms ${ }^{\mathrm{b}}$ & 1.55 & .55 \\
\hline $\begin{array}{l}\text { General Perceptions of Visitation and } \\
\text { Therapy Dogs on Campus }{ }^{c}\end{array}$ & 1.65 & .69 \\
\hline $\begin{array}{l}\text { Perceptions of Interactions with Visitation } \\
\text { and Therapy Dogs on Campus }{ }^{\mathrm{d}}\end{array}$ & 1.94 & .48 \\
\hline
\end{tabular}

\section{Student, Faculty, and Staff Respondent Comparisons}

Comparisons were made between responses of students, faculty, and staff. For general perceptions of dogs, student respondents had a mean of 1.75 with a standard deviation of .41 , faculty had a mean of 2.03 with a standard deviation of .46 , and staff 
had a mean of 1.90 with a standard deviation of .43. For perceived knowledge of terms, students had a mean of 1.75 and a standard deviation of .54, faculty had a mean of 1.62 and a standard deviation of .58, and staff had a mean of 1.82 and a standard deviation of .55. The construct of general perceptions of dogs on campus had a mean of 1.75 with a standard deviation of .63 for students, a mean of 2.03 and a standard deviation of .75 for faculty, and a mean of 1.82 and a standard deviation of .68 for staff. For the construct of perceptions of interactions with dogs on campus, students had a mean of 1.84 and a standard deviation of .43, faculty had a mean of 2.23 and a standard deviation of .53 , and staff had a mean of 2.06 and a standard deviation of .48. (see Table 16).

Table 16

Student, Faculty, and Staff Comparisons

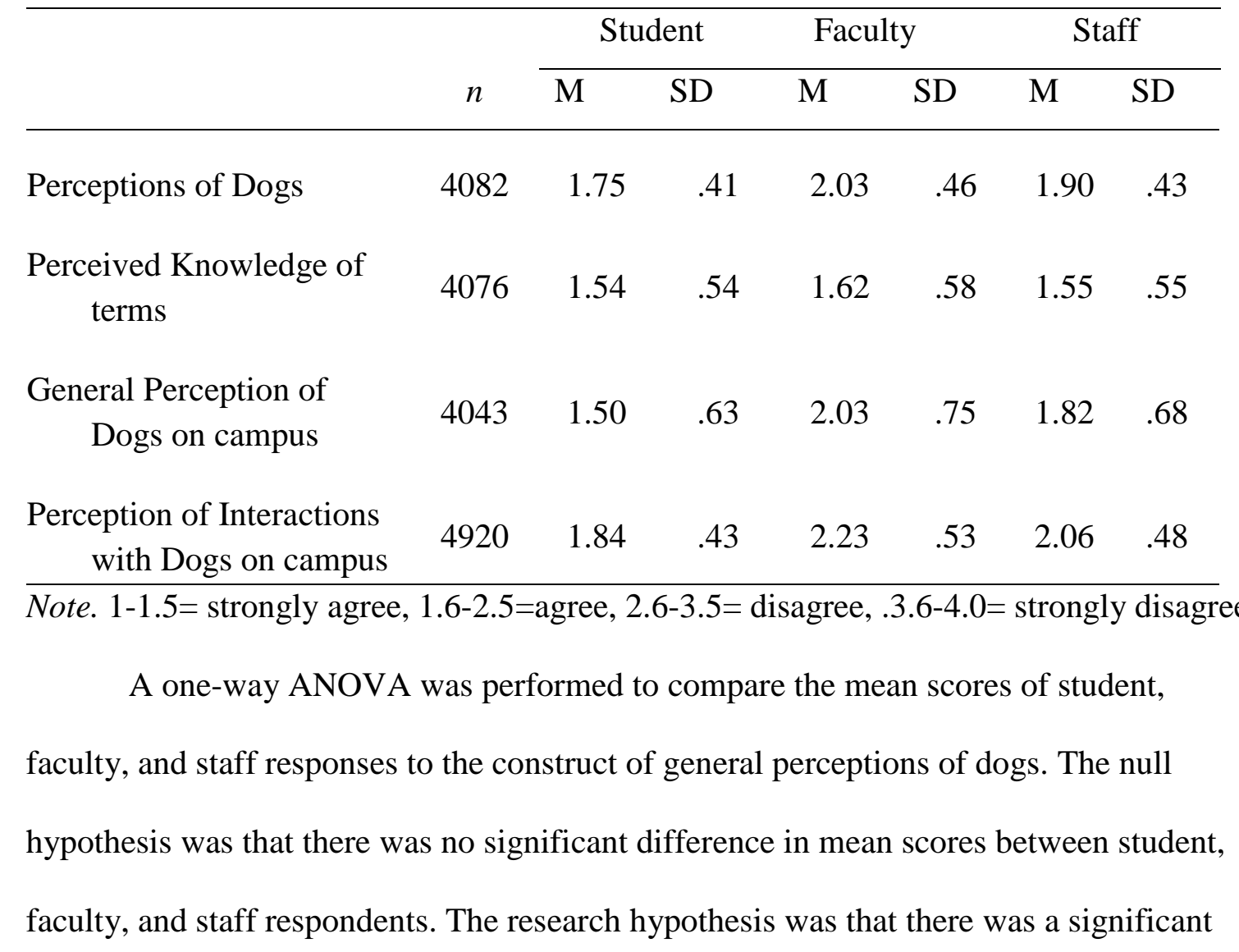


difference between student, faculty, and staff respondents mean scores. The ANOVA produced an F value of 12.07 and was significant at an alpha of .05. The null hypothesis was rejected, indicating that there was a significant difference between students, faculty, and staff in their general perceptions of dogs (see Table 17).

A Scheffé post-hoc analysis found a significant difference between the mean scores of students, faculty, and staff respondents. Students scored the lowest, followed by staff, with faculty scoring the highest. The lower the scores, the more positively the construct was being perceived by respondents.

A one-way ANOVA was performed to compare the mean scores of student, faculty, and staff responses for the construct of perceived knowledge of the terms "visitation dog," "therapy dog," and "service dog." The null hypothesis was that there was no significant difference in mean scores between student, faculty and staff respondents. The research hypothesis was that there was a significant difference between student, faculty, and staff respondents' mean scores for the construct of perceived knowledge of terms. The ANOVA had an F value of 4.85 and was significant at an alpha of .05. The null hypothesis was rejected, and the alternate hypothesis was accepted, indicating that there was a significant difference between student, faculty, and staff respondents' mean scores of the construct of perceived knowledge of the terms "visitation," "therapy,” and "service dog” (see Table 17).

A Scheffé post-hoc analysis found a significant difference between the mean scores of both students and faculty and staff and faculty, but no significant difference was reported between students and staff. Faculty scored the lowest, followed by staff, with 
students scoring the highest. The lower the scores, the more strongly respondents felt they knew the terms "visitation dog," “therapy dog,” and "service dog.”

A one-way ANOVA was performed to compare the mean scores of student, faculty, and staff responses mean scores for the construct of general perceptions of visitation and therapy dogs on campus. The null hypothesis was there was no significant difference in mean scores between student, faculty and staff respondents. The research hypothesis was there was a significant difference between student, faculty, and staff respondents’ mean scores for the construct of general perceptions of visitation and therapy dogs on campus. The ANOVA produced an F value of 180.28 and was significant at an alpha of .05. The null hypothesis was rejected, and the alternate hypothesis was accepted, indicating that there was a significant difference between student, faculty, and staff respondents on general perceptions of having visitation and therapy dogs on campus (see Table 17).

A Scheffé post-hoc analysis found a significant difference between the mean scores of students, faculty, and staff respondents. Students scored the lowest, followed by staff, with faculty scoring the highest. The lower the scores, the more positively the construct was being perceived by respondents.

A one-way ANOVA was performed to compare the mean scores of student, faculty, and staff responses for the construct of perception of interactions with visitation and therapy dogs on campus. The null hypothesis posited that there was no significant difference in mean scores between student, faculty, and staff respondents. The research hypothesis posited there was a significant difference between student, faculty, and staff respondents' mean scores for the construct of perception of interactions with visitation 
and therapy dogs on campus. The ANOVA produced an F value of 187.903 and was significant at an alpha of .05. The null hypothesis was rejected and the alternate hypothesis was accepted, indicating that there was a significant difference between student, faculty, and staff respondents in their perceptions of interactions with dogs on campus (see Table 17).

A Scheffé post-hoc analysis found a significant difference between the mean scores of students, faculty, and staff respondents. Students scored the lowest, followed by staff, with faculty scoring the highest. The lower the scores, the more positively the construct was being perceived by respondents (see Table 17). 
Table 17

Analysis of Variance: General perceptions of dogs, Perceived Knowledge of Terms, General Perception of Dogs on Campus and Perception of Interactions with Dogs on Campus by Students, Faculty, and Staff Respondents.

\begin{tabular}{|c|c|c|c|c|c|}
\hline Source & & SS & DF & MS & $\mathrm{F}$ \\
\hline \multirow[t]{3}{*}{ General Perceptions of Dogs ${ }^{\mathrm{a}}$} & Between Groups & 43.49 & 2 & 21.75 & $12.07^{*}$ \\
\hline & Within Groups & 714.94 & 4079 & .18 & \\
\hline & Total & 758.44 & 4081 & & \\
\hline \multirow{3}{*}{$\begin{array}{l}\text { Perceived Knowledge of the Terms Visitation, Therapy } \\
\text { and Service Dog }\end{array}$} & Between Groups & 2.94 & 2 & 1.470 & $4.86^{*}$ \\
\hline & Within Groups & 1231.88 & 4073 & .302 & \\
\hline & Total & 1234.82 & 4075 & & \\
\hline General Perception of Visitation and Therapy Dogs on & Between Groups & 158.11 & 2 & 79.055 & $180.29 *$ \\
\hline \multirow[t]{2}{*}{ Campus $^{\mathrm{c}}$} & Within Groups & 1771.53 & 4040 & .44 & \\
\hline & Total & 1929.64 & 4042 & & \\
\hline Perceptions of Interactions with Visitation and Therapy & Between Groups & 79.28 & 2 & 39.64 & $187.91 *$ \\
\hline \multirow[t]{2}{*}{ Dogs on Campus ${ }^{\mathrm{d}}$} & Within Groups & 826.30 & 3917 & .21 & \\
\hline & Total & 905.58 & 3919 & & \\
\hline
\end{tabular}

Note. ${ }^{a} n=4082,{ }^{b} n=4076,{ }^{c} n=4043,{ }^{d} n=4920,{ }^{*} \alpha \leq .05,2-2.5=$ strongly agree, $1.5-1.9=$ agree, $1-1.49=$ disagree, $.5-1.9=$ strongly disagree 


\section{Comparison of International Students, International Faculty, and International \\ Staff Members to Non- International Students, Faculty, and Staff}

A t-test was used to determine if a statistical difference existed in the mean scores of those who indicated being an international student, international staff member, or international faculty member (group 1) and those who identified as non-international (group 2) for the construct of general perceptions of dogs. The null hypothesis for each construct was Ho $=M_{\text {group } 1}=M_{\text {group2 }}$. The alternative hypothesis was $\mathrm{H}_{1}=\mathrm{M}_{\text {group } 1} \neq$ Mgroup2.

The mean score for group 1 was 2.14 with a standard deviation of .58. The mean scores for group 2 was 1.8 with a standard deviation of .42 (see Table 18).

A t-test statistical analysis was used to compare the means of group one and group two, the statistical analysis results $(t=10.47$, $\mathrm{df}=4070)$ were significant at $\alpha \leq .05$. The null hypothesis was rejected and the alternative hypothesis, $\mathrm{H}_{1}=\mathrm{M}_{\mathrm{yes}} \neq \mathrm{M}_{\text {no. There was a }}$ significant difference between the mean test scores of those who indicated they were an international student, international faculty member, or international staff member at WVU, indicating that international students, international faculty, and international staff members' general perceptions of dogs are statistically different than those who are not international college community members. The scores of those who considered themselves international community members had higher mean scores, indicating they did not have as positive perceptions of dogs in general as compared to community members who were non- international (see Table 18). 
A t-test was used to determine if a statistical difference existed in the mean scores of those who indicated being and international student, international staff, or international faculty member (group 1) and identified as non-international (group 2) for the construct of perceived knowledge of the terms visitation dog, therapy dog and service dog. The null hypothesis for each construct was Ho $=\mathrm{Mgroup} 1_{\mathrm{g}}=\mathrm{M}_{\text {group2}}$. The alternative hypothesis was $\mathrm{H}_{1}=\mathrm{M}_{\text {group } 1} \neq \mathrm{M}_{\text {group2 }}$.

The mean scores for group 1 were 1.9 with a standard deviation of .71 . The mean scores for group 2 was 1.5 with a standard deviation of .53 (see Table 18).

A t-test statistical analysis was used to compare the means of group 1 and group 2. The statistical analysis results $(t=9.886, \mathrm{df}=4064)$ were significant at $\alpha \leq .05$. The null hypothesis was rejected and the alternative hypothesis, $\mathrm{H} 1=$ Myes $\neq$ Mno was accepted. There was a significant difference between the mean scores of those who indicated they consider themselves an international student, international faculty, or international staff member at WVU when compared to those who do not. This indicates that international students, international faculty, and international staff members’ perceived knowledge of terms was significantly different than those who were not international college community members. The scores of those who considered themselves international community members had higher mean scores, indicating they did not feel they knew the terms "visitation dog," “therapy dog,” and "service dog” as well as those who were non-international community members.

A t-test was used to determine if a statistical difference existed in the mean scores of those who indicated being an international student, international staff member, or international faculty member (group 1) and those who identified as non-international 
(group 2) for the construct of general perception of visitation and therapy dogs on college campuses. The null hypothesis for each construct was $\mathrm{Ho}=\mathrm{M}_{\text {group1 }}=\mathrm{M}_{\text {group2 }}$. The alternative hypothesis was $\mathrm{H}_{1}=\mathrm{M}_{\text {group } 1} \neq \mathrm{M}_{\text {group2}}$.

The mean scores for group 1 were 2.00 with a standard deviation of .82. The mean scores for group 2 were 1.63 with a standard deviation of .68 (see Table 18).

A t-test statistical analysis was used to compare the means of group 1 and group 2. The statistical analysis results $(t=7.088, \mathrm{df}=4032)$ were significant at $\alpha \leq .05$ for the construct of general perceptions of visitation and therapy dogs on college campus. The null hypothesis was rejected and the alternative hypothesis, $\mathrm{H} 1=$ Myes $\neq$ Mno. There was a significant difference between the mean test scores of those who indicated they consider themselves an international student, international faculty member, or international staff member at WVU when compared to those who do not. This indicates that international students, international faculty, and international staff members' general perceptions of visitation and therapy dogs on college campuses are significantly different than those who are not international college community members. The scores of those who considered themselves international community members had higher mean scores, indicating they did not perceive having visitation and therapy dogs on campus as positively as those who were non-international community members.

A t-test was used to determine if a statistical difference existed in the mean scores of those who indicated being an international student, international staff member, or international faculty member (group 1) and those who identified as non-international (group 2) for the construct of perceptions of interactions with visitation and therapy dogs 
on college campuses. The null hypothesis for each construct was Ho $=\mathrm{M}_{\text {group1 }}=\mathrm{M}_{\text {group2 }}$.

The alternative hypothesis was $\mathrm{H}_{1}=\mathrm{M}_{\text {group } 1} \neq \mathrm{M}_{\text {group2 }}$.

The mean scores for group 1 were 2.15 with a standard deviation of .62. The mean scores for group 2 were 1.93 with a standard deviation of .47 (see Table 18).

A t-test statistical analysis was used to compare the means of group 1 and group 2.The statistical analysis results $(t=6.051, \mathrm{df}=3909)$ were significant at $\alpha \leq .05$. The null hypothesis was rejected and the alternative hypothesis, $\mathrm{H} 1=$ Myes $\neq$ Mno. There was a significant difference between the mean scores of those who indicated that they consider themselves an international student, international faculty member, or international staff member at WVU when compared to those who do not. This indicates that international students, international faculty members, and international staff members’ general perceptions of interactions with visitation and therapy dogs on campus were significantly different than those who are not international college community members. The scores of those who considered themselves international community members had higher mean scores, indicating they did not perceive having visitation and therapy dogs in campus as positively as those who were non-international community members. (see Table 18). 
Table 18

Comparison of Mean Scores of International Students, International Faculty, and International Staff Compared to Non-International Students, International Faculty, and International Staff Members for Each Construct

\begin{tabular}{|c|c|c|c|c|c|c|}
\hline & & $\mathrm{N}$ & $M$ & $S D$ & $D f$ & $t$ \\
\hline \multirow[t]{2}{*}{ General Perception of Dogs } & Group 1 & 188 & 2.14 & .58 & 196.46 & $7.77 *$ \\
\hline & Group 2 & 3884 & 1.81 & .42 & & \\
\hline \multirow{2}{*}{$\begin{array}{l}\text { Perceived Knowledge of } \\
\text { Terms }\end{array}$} & Group 1 & 188 & 1.93 & .71 & 197.31 & $6.62^{*}$ \\
\hline & Group 2 & 3878 & 1.53 & .53 & & \\
\hline \multirow{2}{*}{$\begin{array}{l}\text { General Perception of } \\
\text { Visitation and Therapy } \\
\text { Dogs on Campus }\end{array}$} & Group 2 & 185 & 2.00 & .82 & 196.26 & $5.96 *$ \\
\hline & Group 2 & 3849 & 1.64 & .68 & & \\
\hline \multirow{2}{*}{$\begin{array}{l}\text { Perception of Interactions } \\
\text { with Visitation and Therapy } \\
\text { Dogs on Campus }\end{array}$} & Group 1 & 180 & 2.15 & .62 & 189.282 & $4.75^{*}$ \\
\hline & Group 2 & 3731 & 1.93 & .47 & & \\
\hline
\end{tabular}




\section{CHAPTER 5}

\section{Summary, Conclusion, Recommendations}

\section{Purpose of Study}

This study was conducted with three core purposes. The first purpose was to identify how students, faculty, and staff interact with visitation and therapy dogs on West Virginia University campuses. The second purpose sought to describe how students, faculty, and staff perceive visitation and therapy dogs on West Virginia University Campuses. The third purpose sought to determine if the diverse population on college campuses affects the perceptions of visitation and therapy dogs at West Virginia University Campuses.

\section{Objectives of the Study}

To meet the above purposes, several objectives were developed:

1. Describe student, faculty, and staff perception of dogs

2. Describe how students, faculty, and staff interact with visitation and therapy dogs on campus

3. Describe how students, faculty, and staff perceive their interaction with visitation and therapy dogs on campus

4. Identify differences between students, faculty, and staff demographics and their perceptions of interactions with visitation and therapy dogs

\section{Summary, Conclusions and Discussion}

The following recommendations and conclusions are based on the findings of this descriptive study. The data in this study provided an introductory understanding to how students, faculty, and staff perceive the use of visitation and therapy dogs on campus. 
Interactions with visitation and therapy dogs are being positively ( $\mathrm{M}=1.94$; $\mathrm{SD}=.48$ ) perceived by the campus community.

General perceptions of dogs were positive among a majority of the population. A clear majority of the respondents indicated they generally liked dogs (95.62\%) and that dogs can help people reduce stress (96.45\%). Additionally, the majority of respondents (82.72\%) disagreed or strongly disagreed to being afraid of dogs. It should be noted that a vast majority (90.14\%) of respondents also indicated they have lived with a dog. The general perceptions section of this survey did not look to identify how individuals felt about visitation or therapy dogs on campus and only asked questions about dogs in general. Understanding respondents' general perceptions of dogs develops a foundation for this study to further identify the campus community's feelings of dogs, and visitation and therapy dogs on campus. Previous literature on the use of visitation and therapy dogs in educational settings has encountered a lack of diversity within respondents (Friesen, 2009). Similarly, the clear majority of respondents in this study were non-international (95.39\%). Furthermore, 91.49\% indicated their ethnicity as white. If a population has an unfavorable general perception of dogs, it is likely that more negative trends of perceptions of visitation and therapy dogs will arise. When implementing visitation and therapy dogs on college campuses, it can be recommended to assess the general perceptions of dogs within the campus community.

Findings indicated $65.64 \%$ of respondents interacted with a visitation or therapy dog at least once a semester and $85.67 \%$ have seen a visitation or therapy dog on campus at least once a semester. Most respondents (84.81\%) indicated they wanted to see more visitation and therapy dogs on campus and that they were more likely to go into an office 
if a dog was present. However, there were 205 respondents (5.75\%) who indicated they have avoided an area on campus because a visitation or therapy dog was present. The location of visitation and therapy dogs on college campuses should be seriously examined. . If visitation and therapy dogs are present in an area where campus community members are required to attend, the presence of a visitation or therapy dog may not be appropriate. Having scheduled times for visitation and therapy dogs or using visitation and therapy dogs for voluntary events would provide a more inclusive environment for all campus community members. Additionally, proper or favorable handling should be investigated. More research should be conducted to identify the safest way to accommodate visitation and therapy dogs in public.

This study earlier identified the difference between visitation dogs, therapy dogs, and service dogs. Although primarily visitation dogs are being utilized on West Virginia University campuses, only $69.52 \%$ of respondents indicated knowing what a visitation dog is. Alternatively, $95.51 \%$ of respondents indicated knowing what a therapy dog is and $98.20 \%$ indicated knowing what a service dog is. This study did not assess whether respondents actually did know or were correct in their definitions, but only assessed if they thought they knew the definition of each term. Educating the intended benefactors and others in contact with visitation and therapy dogs is an important part of implementing visitation and therapy dogs into a community. Guidelines found in a study conducted in a regional cancer center in northern California could also be useful in an educational setting (Bibbo, 2013). In this setting, patients and staff members were informed of the future presence of therapy dogs. Prior to the therapy dogs' arrival, staff 
members verbally cleared the area to ensure that no patients with fears, dislikes, or allergies to dogs were present.

It may also be beneficial to educate the students, staff, and faculty who attend the colleges that utilize visitation dogs on a regular basis regarding how to interact with visitation dogs and how a therapy dogs differs from service animals. For example, service dogs should not be approached or petted while working, while visitation and therapy dogs on campus are intended for students to approach and interact with. It is also recommended further research be conducted to assess if a population can correctly identify a visitation, therapy, or service dog and their uses.

Most respondents (91.92\%) indicated that the presence of visitation and therapy dogs are good for WVU campuses and that they were more likely to talk to a person if they were handling a visitation or therapy dog on campus (71.41\%). Only 3.11\% of respondents indicated being afraid of visitation and therapy dogs on campus. Although some respondents indicated they were fearful of visitation and therapy dogs on campus, it should be recognized that the goal of having visitation and therapy dogs on campus is to benefit the students. If visitation and therapy dogs are evoking fear or causing stress for an individual, these fears should not be ignored. This supports the previous recommendation to utilize visitation and therapy dogs in voluntary events or during scheduled times so those who have adverse feelings towards visitation and therapy dogs can still feel safe in a particular area, such as a classroom or office. A further recommendation is to clearly that indicate a visitation or therapy dog is present, so campus community members are never surprised by the presence of a visitation or therapy dog on campus. It may also be beneficial to provide a simple email to students, 
staff, and faculty introducing them to the dog, explaining their purpose, and how to interact with the dog.

When respondents indicated their perceptions of their interactions with visitation and therapy dogs on campus, $71.94 \%$ indicated they personally benefit from an interaction with a visitation or therapy dog on campuses, while only $6.12 \%$ of respondents indicated feeling uncomfortable because of a visitation or therapy dog on campus. Overall , most respondents regard visitation and therapy dogs positively. Implementing more visitation and therapy dogs on college campuses has the potential to have a positive effect on student morale, stress levels, and attendance to voluntary events; however, careful consideration and education is needed to prevent the percentage of campus community members who are uncomfortable around dogs from feeling additional stress or anxiety due to the dog's presence.

Respondents who indicated being an international student, international faculty member, or international staff member had higher mean scores when compared to those who did not for each of the following constructs: general perception of dogs, perceived knowledge of terms, general perception of visitation and therapy dogs on campus, and perceptions of interactions with visitation and therapy dogs on campus. Higher mean scores indicated that international community members did not perceive dogs as positively as those who did were non-international. However, only 188 participants (4.61\%) indicated being an international member of the WVU community. The lack of diversity in the demographics of this study suggests more research should be conducted in a more diverse population to better understand how visitation and therapy dogs should be managed in a community with different cultures coming together in one area. 


\section{Conclusions}

This research was successful in meeting the purpose and objectives of this study. Results of this study focused on the constructs of general perception of dogs, perceived knowledge of dogs, general perception of visitation and therapy dogs on campus, and perceptions of interactions with visitation and therapy dogs on campus.

The use of visitation and therapy dogs on campus appears to be well-received by the members of the West Virginia University community. Many respondents indicated that visitation and therapy dogs can reduce stress and are a good thing for the university. Findings also indicate that respondents would like to see more visitation and therapy dogs on campus. Although most respondents responded positively towards visitation and therapy dogs on campus, it should be noted that 476 respondents $(14.10 \%)$ indicated that visitation and therapy dogs have caused stress in their workplace or in their learning environment.

\section{Conclusions}

The findings of this research were successful in meeting the purpose and objectives of this study. Results of this study focused on the constructs of general perception of dogs, perceived knowledge of dogs, general perception of visitation and therapy dogs on campus, and perceptions of interactions with visitation and therapy dogs on campus.

\section{Recommendations}

Based on this study's findings, the following recommendations can be presented. With perceptions of having visitation and therapy dogs on campus being positive, it is important for the industry to develop management techniques to improve the use of 
visitation and therapy dogs in a college campus setting. Though negative responses were few, with 476 respondents indicating visitation and therapy dogs causing stress in their workplace or learning environment, this number may increase with increased use of visitation and therapy dogs. Handlers and trainers should make it a priority to understand stressors caused by visitation and therapy dogs on campuses. More research on this topic should be conducted to more specifically identify the stressors being created and how to alleviate those stressors.

Research has identified the possible benefits of using visitation or therapy dogs for relieving stress and to provide means of social lubrication (Zents, Fisk \& Lauback, 2017). This study supports this notion, but also identifies issues that have begun to arise in the industry. Respondents did not feel confident with their knowledge of the function of a visitation dog, even though visitation dogs are primarily used on WVU campuses. More educational initiatives should be implemented when introducing a visitation or therapy dog into an environment.

Moving forward, colleges, administrations, and practitioners will be interested to know that visitation and therapy dogs are generally being positively received by the campus community and continuing to implement visitation and therapy dogs may be beneficial to students. 


\section{REFERENCES}

Anderson, K. L., \& Olson, M. R. (2006). The value of a dog in a classroom of children with severe emotional disorders. Anthrozoos, 19(1), 35-49.

Baun, M. M., Bergstorm, N., Langston, N. F., \& Toma, L. (1983). Physiological effects of petting dogs: Influences of attachment. American Journal of Nursing, 162(170).

Bibbo, J. (2013, July). Staff members' perceptions of an animal-assisted activity. Oncology Nursing Forum, 40(4), E320-E326.

Binfet, J. (2017). The effects of group administered canine therapy on university students' well being: A randomized controlled trial. Anthrozoos, 30(3), 397-414. doi:10.1080/08927936.2017.1335097

Blogger, G. (2011, July 22). Therapy dog offers stress relief at work. In Harvard Health Blog. Retrieved from, https://www.health.harvard.edu/blog/therapy-dog-offersstress-relief-at-work-201107223111

Bowman, N. A. (2014). Conceptualizing openness to diversity and challenge: Its relation to college experiences, achievement, and retention. Innovative Higher Education, 39, 277-291.

Borrego, J. L., Franco, L. R., Mediavilla, M. P., Pinero, N. B., Roldan, A. T., \& Picabia, A. B., (2014). Animal-assisted interventions: Review of current status and future challenges. International Journal of Psychology and Psychological Therapy, 14(1), 85. 
Brougham, R. R., Zail, C. M., Mendoza, C. M., \& Miller, J. R. (2009). Stress, sex differences, and coping strategies among college students. Current Psychology: A Journal for Diverse Perspectives on Diverse Psychological Issues, 28(2), 85-97. doi:10.1007/s12144-009-9047-0

Byrd, D., \& McKinney, K. (2012). Individual, interpersonal, and institutional level factors associated with the mental health of college students. Journal of American College Health, 60, 185-193. doi:10.1080/07448481.2011.584334.

Crossman, M. K., \& Kazdin, A. E. (2015). Animal visitation programs in colleges and universities: An efficient model for reducing student stress. In A. Fine (Ed.), Handbook on animal-assisted therapy: Theoretical foundations and guidelines for practice (4th ed., pp. 333-337). Burlington, MA: Academic

Daltry, R. M., \& Mehr, K. E. (2015). Therapy dogs on campus: recommendations for counseling center outreach. Journal of College Student Psychotherapy, 29, 72-78. doi:10.1080/87568225.2015.976100

Fine, A. H., \& Beck, A. (2010). Understanding our kinship with animals: input for health care professionals interested in the human animal bond. Handbook on Animal Assisted Therapy, 3, 4-15. doi:10.1016/B978-0-12-381453-1.10001-7

Friesen, L. (2009, October 6). Exploring animal assisted programs with children in school and therapeutic contexts. Springer Science + Business Media LLC, 37, 261-276. doi:10.1007/s10643-009-0349-5

Granger, B. P., Kogan, L., Fitchett, J., \& Helmer, K. (1998). A human-animal intervention team approach to animal assisted therapy. Anthrozoos, 11(3). 
Haggerty, J. M., \& Mueller, M. K. (2017). Animal-assisted stress reduction programs in higher education. Innovation Higher Education, 42, 379-389. doi:10.1007/s10755-017-9392-0

Jalongo, M. R., Astroino, T., \& Bomboy, N. (2004, August). Canine visitors: the influence of therapy dogs on young children's learning and well-being in classroom hospitals. Early Childhood Education Journal, 32, 9-16. doi:10823301/04/0800-0009/0

Jalongo, M. R., \& McDevitt, T. (2015). Therapy dogs in academic libraries: a way to foster student engagement and mitigate self reported stress during finals. Routledge Taylor \& Friends, 11, 254-269. doi:10.1080/15228959.2015.1084904

Lee, C., Dickson, D. A., Conley, C. S., \& Holmbeck, G. N. (2014). A closer look at selfesteem, perceived social support, and coping strategy: A prospective study of depressive symptomatology across the transition to college. Journal of Social and Clinical Psychology, 33(6), 560-585. doi:10.1521/jscp.2014.33.6.560

Levinson, B. M. (1984). Human/companion animal therapy. Journal of Contemporary Psychology, 14(2), 131-144.

Moody, W.J., King, R., \& O'Rourke, S. (2002). Attitudes of pediatric medical ward staff to a dog visitation program. Journal of Clinical Nursing, 11,537-543. 
Muckle, J., \& Lasikiewicz, N. (2017). An exploration of the benefits of animal-assisted activities in undergraduate students in Singapore. Asian Journal of Social Psychology, 20, 75-84. doi:10.1111/ajsp.12166

Parenti, L., Forman, A., Mead, J., \& Wirth, O. (2013, November 6). A revised taxonomy of assistance animals. JRRD, 50, 745-756.

Picard, M. J. (2015). Study of the effect of dogs on college students' mood and anxiety (Master's thesis). Retrieved from http://digitalcommons.library.umaine.edu/honors/233

Scozato, I., Zaninotto, L., Romano, M., Menardi, C., Cavedon, L., Pegoraro, A., \& Socche, L. (2017). Effects of dog-assisted therapy on communication and basic social skills of adults with intellectual disabilities: a pilot study. Intellectual and Developmental Disabilities, 55(3), 125-138. doi:10.1352/1934-9556-55.3.125

Triebenbacher, S. L. (1998). Pets as transitional objects: Their role in children's emotional development. Psychological Reports, 82, 191-200.

Wells, D. (2009, September). The effects of animals on human health and wellbeing. Journal of Social Science Issues, 65(3), 523-543. doi:10.1111/j.15404560.2009.01612.x

Wells, M., \& Perrine, R. (2001). Pets go to college: the influence of pets on students perceptions of faculty and their offices. Anthrozoos, 14(3). doi:0.2752/089279301786999472 
Zents, C. E., Fisk, A. K., \& Lauback, C. W. (2017). Paws for intervention: perceptions about the use of dogs in schools. Journal of Creativity and Health, 12(1), 82-98. doi:10.1080/15401383.2013.118971 
APPENDIX I

COVER LETTER 
March 29, 2015

Dear Student, Faculty member or Staff member at West Virginia University:

As a current student, faculty member or staff member of the West Virginia University, you are key in understanding how dogs on college campus are affecting this community. You are a valued representative of community here at West Virginia University.

I am Brieanna Hughes, a graduate student in Agricultural and Extension Education; and under the direction of my advisor, Dr. Jessica M. Blythe, we are conducting research using a survey to determine the perceptions and feelings of visitation and therapy dogs on campus. The results will be used to prepare a thesis to partially fulfill the requirements for a Master's of Science degree in Agricultural and Extension Education.

We are contacting all students, faculty members, and staff members at West Virginia University on campuses located in Morgantown, WV. The results will provide information on perceptions of the use of visitation and therapy dogs on West Virginia University campuses, to better understand the best practices for visitation and therapy dogs on college campuses.

Please take a few moments and share your opinions with us.

Participation in this research study is completely voluntary and all information you provide will be held as confidential as possible. The survey should only take about fifteen minutes to complete, and your response to the survey is crucial to the success of the study. You may skip any question you are not comfortable answering and you can stop at any time. Survey results will be reported in a summary format and individual responses will not be identifiable.

The Institutional Review Board (IRB) at West Virginia University has acknowledged this study. If you have any questions or concerns about completing the questionnaire or about being in this study, you may contact me at Bgh0002@mix.wvu.edu or my advisor Dr. Jessica Blythe at jessica.blythe@mail.wvu.edu.

Please click the highlighted link below to access the study no later than April 15th. Thank you in advance for your assistance with this research effort. We sincerely appreciate your participation.

Sincerely,

Brieanna Hughes

Masters Student

Jessica Blythe, Ph.D

Education

Assistant Professor: Agricultural 
APPENDIX II

FOLLOW-UP EMAILS 


\section{Follow Up Email \#1}

April 10, 2018

Dear Students, Faculty and Staff:

Last week we sent an email to you asking for your participation in the study exploring the use of visitation and therapy dogs on WVU campuses.

This study is very important and your input is vital to its success. The study closes $\mathbf{0 5 / 0 4 / 1 8}$. The goal of this study is to gain more information on the feelings of the college community of visitation and therapy dogs on campus.

To complete this survey, simply click on this link:

The results will remain confidential and will not be able to identify a specific individual. The results will be used to help understand the use of visitation and therapy dogs on college campuses. Please complete the survey to ensure success of this study. This study is very important and your input is vital to its success. The study closes 05/04/18. The goal of this study is to gain more information on the feelings of the college community of visitation and therapy dogs on campus. The results will remain confidential and will not be able to identify a specific individual. The results will be used to help understand the use of visitation and therapy dogs on college campuses. Please complete the survey to ensure success of this study. The Institutional Review Board (IRB) at West Virginia University has acknowledged this study. If you have any questions or concerns about completing the questionnaire or about being in this study, you may contact me at Bgh0002@mix.wvu.edu.

Follow the link to opt out of future emails:

$\$\{1: / / O p t O u t L i n k ? d=C l i c k$ here to unsubscribe $\}$

Sincerely,

Brieanna Hughes

Jessica Blythe, Ph.D

Masters Student

Assistant Professor: Agricultural

Education 


\section{Follow Up Email \#2}

April 16, 2018

Dear Students, Faculty and Staff:

Recently we sent an email to you asking for your participation in the study exploring the use of visitation and therapy dogs on campus. Thank you to those who have completed the survey. To those individuals that have not, there is still time.

Follow this link to the Survey:

$\$\{1: / /$ SurveyLink?d=Take the Survey $\}$

Or copy and paste the URL below into your internet browser:

$\$\{1: / /$ SurveyURL $\}$

This study is very important and your input is vital to its success. The study closes 05/04/18. The goal of this study is to gain more information on the feelings of the college community of visitation and therapy dogs on campus. The results will remain confidential and will not be able to identify a specific individual. The results will be used to help understand the use of visitation and therapy dogs on college campuses. Please complete the survey to ensure success of this study. The Institutional Review Board (IRB) at West Virginia University has acknowledged this study. If you have any questions or concerns about completing the questionnaire or about being in this study, you may contact me at Bgh0002@mix.wvu.edu.

Follow the link to opt out of future emails:

$\$\{1: / / O p t O u t L i n k ? d=C l i c k$ here to unsubscribe $\}$

Sincerely,

Brieanna Hughes

Jessica Blythe, Ph.D

Masters Student

Assistant Professor: Agricultural

Education 
Follow Up Email \#3

April 5, 2018

Dear Students, Faculty and Staff:

Shortly after spring break we contacted you asking for your help in the study exploring the use of visitation and therapy dogs on WVU campuses. We need your help to ensure that the results are precise as possible

This study is very important and your input is vital to its success. The study closes $\mathbf{0 5 / 4 / 1 8}$. The goal of this study is to gain more information on the feelings of the college community of visitation and therapy dogs on campus.

Follow this link to the Survey:

$\$\{\mathrm{l}: / /$ SurveyLink?d=Take the Survey $\}$

Or copy and paste the URL below into your internet browser:

$\$\{1: / / S u r v e y U R L\}$

The results will remain confidential and will not be able to identify a specific individual. The Institutional Review Board (IRB) at West Virginia University has acknowledged this study. The results will be used to help understand the use of visitation and therapy dogs on college campuses. Please complete the survey to ensure success of this study.

Thank you for considering our request during this busy time of year.

Follow the link to opt out of future emails:

$\$\{1: / / O p t O u t L i n k ? d=C l i c k$ here to unsubscribe $\}$

Sincerely,

Brieanna Hughes

Masters Student

Jessica Blythe, Ph.D

Education

Assistant Professor: Agricultural 


\section{Follow Up Email \#4}

April 10, 2018

Dear Students, Faculty, and Staff,

We a writing to follow up on a message we sent last week asking you to participate in a study exploring the use of visitation and therapy dogs on WVU campuses. The assessment of the perceptions of visitation and therapy dogs on campus is coming to a close; this is the last reminder we are sending.

To complete this survey please select the link below:

Thank you in advance for your participation in this study. This information you provide is vital for its success. If you have any questions or concerns about completing the questionnaire or about being in this study, you may contact me at Bgh0002@mix.wvu.edu. 
APENDIX III

\section{SURVEY QUESTIONS}




\section{Perceptions of Dogs - without knowing about thier interactions}

Using the scale below please indicate if you agree or disagree with the following statements about dogs in general.

$\begin{array}{lcccc} & \text { Strongly } & \text { Agree } & \text { Disagree } & \text { Strongly } \\ \text { disagree }\end{array}$

\section{Interaction - who what where on Wvu Campus}

Using the scale below please indicate the degree you agree or disagree with the following statements about visitation and/or therapy dogs in general. 


$\begin{array}{lcccc} & \text { Strongly Agree } & \text { Agree } & \text { Disagree } & \begin{array}{c}\text { Strongly } \\ \text { disagree }\end{array} \\ \begin{array}{l}\text { I know what a service } \\ \text { dog is }\end{array} & 0 & 0 & 0 & 0 \\ \begin{array}{l}\text { I know what a visitation } \\ \text { dog is }\end{array} & 0 & 0 & 0 & 0 \\ \begin{array}{l}\text { I know what a therapy } \\ \text { dog is }\end{array} & 0 & 0 & 0 & 0\end{array}$

For the purpose of this survey a visitation or therapy should be considered any dog specifically used for stress relief or social benefits for students on WVU campuses.

Typically, these dogs are seen around campus wearing a vest that has "visitation dog" or "therapy dog" embroidered to the vest.

Using the scale below please indicate how how often you see, hear and interact with visitation and/or therapy dogs on West Virginia University Campuses.

\begin{tabular}{l|ccc} 
& $\begin{array}{c}\text { Almost Every } \\
\text { day }\end{array}$ & $\begin{array}{c}\text { Two to Three times a } \\
\text { week }\end{array}$ & $\begin{array}{c}\text { Once a } \\
\text { week }\end{array}$ \\
\hline $\begin{array}{l}\text { How often do you see visitation or } \\
\text { therapy dogs on campus? }\end{array}$ & 0 & 0 & 0 \\
$\begin{array}{l}\text { How often do you hear (i.e.barking, } \\
\text { tags jingling, etc.) visitation or therapy } \\
\text { dogs on campus? }\end{array}$ & $\mathrm{O}$ & $\mathrm{O}$ & $\mathrm{O}$ \\
$\begin{array}{l}\text { How often do you interact with } \\
\text { visitation or therapy dogs? }\end{array}$ & $\mathrm{O}$ & $\mathrm{O}$ & $\mathrm{O}$ \\
$\begin{array}{l}\text { How often do you intentionally seek } \\
\text { out a visitation or therapy dog on } \\
\text { campus? }\end{array}$ & $\mathrm{O}$ & $\mathrm{O}$ & $\mathrm{O}$
\end{tabular}

Using the scale below please indicate the degree you agree or disagree with the following statements about visitation and/or therapy dogs on West Virginia University campuses

\begin{tabular}{|c|c|c|}
\hline $\begin{array}{l}\text { Strongly } \\
\text { Agree }\end{array}$ & Agree & Disagree \\
\hline
\end{tabular}




$\begin{array}{cccc}\begin{array}{c}\text { Strongly } \\ \text { Agree }\end{array} & \text { Agree } & \text { Disagree } & \begin{array}{c}\text { Strongly } \\ \text { Disagree }\end{array} \\ 0 & 0 & 0 & 0 \\ 0 & 0 & 0 & 0 \\ 0 & 0 & 0 & 0 \\ 0 & 0 & 0 & 0 \\ 0 & 0 & 0 & 0\end{array}$

Using the scale below please indicate the degree you agree or disagree with the following statements about visitation and/or therapy dogs on West Virginia University campuses

The presence of visitation and therapy dogs are good for WVU campuses

I am more likely to talk to a person if they are handling a visitation or therapy dog

I would like to see more visitation or therapy dogs on campus.

I am afraid of therapy and visitation dogs on campus.

I am more likely to go to an office if a visitation or therapy dog is there

\section{camplises}

I have personally benefited from a visitation or therapy dog on campus

I have avoided an area on campus because visitation or therapy dogs were present

Visitation or therapy dogs have created stress in my work and/or learning environment

I have seen visitation and therapy dogs on campus with out a leash

I have been uncomfortable because of a visitation or therapy dog on campus

I have attended a campus event because I knew a visitation or therapy dog would be there.

I would attend more campus events if I knew visitation or therapy dogs were there

I am less stressed after being around a visitation or therapy dog on campus

I have had a negative experience with a visitation or therapy dog on campus.

I have been unable to tell if a dog is a pet or visitation or therapy on campus.

$\begin{array}{ccccc}\begin{array}{c}\text { Strongly } \\ \text { Agree }\end{array} & \text { Agree } & \text { Disagree } & \begin{array}{c}\text { Strongly } \\ \text { disagree }\end{array} & \text { NA } \\ 0 & 0 & 0 & 0 & 0 \\ 0 & 0 & 0 & 0 & 0 \\ 0 & 0 & 0 & 0 & 0 \\ 0 & 0 & 0 & 0 & 0 \\ 0 & 0 & 0 & 0 & 0 \\ 0 & 0 & 0 & 0 & 0 \\ 0 & 0 & 0 & 0 & 0 \\ 0 & 0 & 0 & 0 & 0 \\ 0 & 0 & 0 & 0 & 0 \\ 0 & 0 & 0 & 0 & 0\end{array}$




$\begin{array}{ccccc}\begin{array}{c}\text { Strongly } \\ \text { Agree }\end{array} & \text { Agree } & \text { Disagree } & \begin{array}{c}\text { Strongly } \\ \text { disagree }\end{array} & \text { NA } \\ 0 & 0 & 0 & 0 & 0 \\ 0 & 0 & 0 & 0 & 0\end{array}$

\section{Demographic}

Please select the title that best describes your role at WVU.

Student

Faculty

Staff

Do you consider yourself an international student, international faculty, or international staff member at WVU?

Yes

No

To which gender identity do you most identify?

Male

Female

Not Listed

Please choose the race you identify with most.

White

Black or African American

American Indian or Alaska Native

Asian

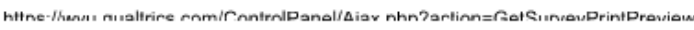


Native Hawaiian or other

Pacific Islander

Other

What is you ethnicity?

Non-hispanic

Hispanic

How would you best describe the environment you grew up in?

Suburban

Urban

Rural

What is your country of origin (homeland)?

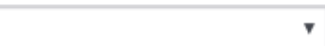

What is your age?

18-24 years old

25-34 years old

35-44 years old

45-54 years old

55-74 years old

75 years or older

Do you currently own a dog?

Yes

No 
Have you ever lived in the same household as a dog?

Yes

No

Are you allergic to dogs?

Yes

No

Powered by Qualtrics 